\title{
LA PLENITUD DE LA DECORACIÓN BARROCA PARA UNA SOCIEDAD BARROCA EN RÍO DE JANEIRO DURANTE EL SIGLO XIX.
}

\section{THE FULLNESS OF BAROQUE DECORATION FOR A BAROQUE SOCIETY IN RIO DE JANEIRO DURING THE NINETEENTH CENTURY.}

\author{
Carlos Javier Castro Brunetto \\ Universidad de La Laguna
}

\begin{abstract}
RESUMEN
El siglo XIX en Río de Janeiro ejemplifica el combate entre el lenguaje barroco que pervive a través de grandes encargos artísticos que se iniciaron en ese periodo, y la progresiva llegada del gusto clásico traído por la Missão Artistica francesa de 1816 invitada por el rey de Portugal d. João VI y que dará lugar, más adelante, a la fundación de la Academia Imperial de Belas Artes. Pero ese enfrentamiento de modelos estéticos no sigue un orden cronológico a la manera de Europa, ni un estilo sucede al otro, sino que conviven en un mismo espacio y tiempo. La pervivencia de las formas organizativas del periodo colonial, la intervención del negro en la creación artística y el mecenazgo eclesiástico favorecieron que la estética barroca no solo subsistiese, sino que cobrase una fuerza extraordinaria, desoyendo los consejos académicos que propugnaban el nuevo orden clasicista. La lucha entre tradición y modernidad, barroco y clasicismo, constituye el objetivo de esta publicación, que a través del análisis de algunos casos prácticos pretende demostrar que Río de Janeiro, en el siglo XIX, también fue una ciudad notoriamente barroca.
\end{abstract}

Palabras clave: Arte, Rio de Janeiro, Brasil, Barroco, Rococó, Clasicismo, Siglo XIX.

\section{ABSTRACT}

The nineteenth century in Rio de Janeiro exemplifies the battle between the Baroque language that survives through great artistic commissions that began in that period, and the progressive arrival of the classical taste brought by the French Missão Artistica of 1816 invited by Joao VI, King of Portugal, and which will, later, lead to the founding of the Imperial Academy of Belas Artes. But this confrontation of aesthetic models does not follow a chronological order in the manner of Europe, nor does one style succeed the other, but coexist in the same space and time. The survival of the organizational forms of the colonial period, the intervention of black in artistic creation and ecclesiastical patronage favored that baroque aesthetics not only survive, but gain extraordinary strength, deomining the academic councils that advocated the new classicist order. The struggle between tradition and modernity, Baroque and classicism, is the aim of this essay, which through the analysis of some case studies seeks to demonstrate that Rio de Janeiro, in the nineteenth century, was also a notoriously Baroque city.

Keywords: Art, Rio de Janeiro, Brazil, Baroque, Rococo, Classicism, XIXth Century. 


\section{EL DISCURSO BARROCO EN EL RÍO DE JANEIRO OCHOCENTISTA.}

La ciudad de Río de Janeiro nació en el contexto de la sociedad barroca y se desarrolló asumiendo los planteamientos arquitectónicos y estéticos llegados de la metrópoli lusitana a lo largo de los siglos XVII y XVIII, con puntuales relaciones con el mundo hispano (hasta 1640) e italiano, hasta el Ochocientos incluido. La ciudad mantuvo ese espíritu cultural incluso después de la llegada en 1808 de la corte de d. João VI de Portugal y los gustos de moda, reforzados tras convertirse en la capital del Brasil independiente en 1822 pero que no acabaron con la estética barroca. Afirmamos, además, que la forma de vida carioca actual, las relaciones interpersonales y los matices singulares de su cultura, como el desfile de las escuelas de samba durante el carnaval, revelan aspectos nacidos en la sociedad barroca colonial que continúan siendo referencias antropológicas y estéticas de la maciza personalidad local (Castro, 2013: 113) y perpetúan formas expresivas de lo barroco que trascienden los siglos, deviniendo en una forma de ser y estar característica de lo que podemos definir como la brasilidad. Esta circunstancia pone de manifiesto que existe un arco temporal de la cultura barroca que no se interrumpió con las pujanzas artísticas y culturales importadas de Europa a lo largo del siglo xIx; dilucidar los fundamentos que nos permiten hablar de un barroco ochocentista constituye el objetivo de este trabajo.

Río de Janeiro nació barroca, no solo por la afirmación del estilo artístico en sí, sino como una forma de vida donde la "pureza" del modelo originario proveniente de la metrópoli, tanto a niveles sociales como culturales, se altera ante la diversa realidad de la colonia. $Y$ las formas artísticas barrocas, de acuerdo con esas mismas estructuras sociales, pervivieron durante todo el siglo XIX en armonía con planteamientos neoclásicos, introducidos por las élites sociales y culturales preferidas por el Brasil independiente y la corte imperial, que buscaban la proximidad de París y la estética napoleónica desde la primera mitad del siglo, reforzada desde la década de 1850 por el deslumbramiento de la corte de Napoleón III y Eugenia de Montijo. Pero Río no abandonó por ello los estímulos sociales manifestados a través del gusto barroco, algo que percibieron nítidamente los viajeros decimonónicos llegados mayoritariamente desde Francia, pero también desde Alemania o Inglaterra, embriagados de la belleza natural que contemplaban, pero estupefactos ante la exuberancia de los flamantes templos, recién decorados con abundancia de rocalla, guirnaldas y frontones partidos, enrollados o con volutas, algo inimaginable en una Europa cada vez más apegada a las fórmulas clásicas. Pero la perplejidad no concluía con esa extraña arquitectura decimonónica anticlásica; en sus diarios recogían una insólita y caótica convivencia de los estratos sociales reunidos bajo el amparo de esas arquitecturas donde la religiosidad popular, incluidos extraños rituales negros que en Europa serían considerados irreverentes. No sabían esos viajeros extranjeros que se hallaban ante las formas más puras del sincretismo religioso, una luz cegadora que emanaba de Río y chocaba con la teoría y la praxis de estos intelectuales, herederos de la Ilustración, que, por aquellos años, como señala Ana María Belluzzo, solo pretendían descortinar esta parte de América Latina, tan desconocida para el mundo europeo (Belluzzo, 2000: 92).

El patrimonio carioca, surgido a finales del siglo XVI, renació en fechas posteriores a 1711, cuando se produjo el feroz ataque y destrucción de la ciudad por el francés DuguyTrouin en el contexto de la Guerra de Sucesión española. La documentación que partirá desde la colonia hacia la metrópoli pidiendo dineros para la reconstrucción es extensísima y hoy se conserva en el Arquivo Ultramarino de Lisboa, con copias decimonónicas en el archivo del Instituto Histórico e Geográfico Brasileiro de Río de Janeiro. Las solicitudes de socorro, o relações que, con mucha suerte a la vez que demora, fueron respondidas, dan una idea de hasta qué punto la ciudad debió ser rehecha y el poco dinero invertido por la metrópoli en este empeño; pero también esa documentación constata que la preocupación de la corona se inclinó en los primeros momentos por el tejido militar de la ciudad, luego por las obras de infraestructura urbana necesarias y en último lugar, por el ornato y ampliación o nueva fundación de lugares de culto. Todo ello está bien documentado por el estudio concienzudo de Nireu Cavalcanti, que aprecia en la arquitectura carioca desde finales del siglo XVII la maciza presencia de los militares, pues todos los ingenieros que construyen las obras más relevantes militares, civiles y religiosas ejercían esa profesión, con una amplia tradición 
en el conocimiento del lenguaje clásico, entre los que destaca en el último cuarto del siglo XVIII Antônio Joaquim de Oliveira, creador de un Aula de Engenharia e Fortificação en 1774 (Cavalcanti, 2004: 294-297).

Así pues, el embellecimiento de los templos habría de esperar a los años finales del siglo XVIII, cuando aumentaron los dineros para ser invertidos en este concepto. En Brasil no existió un mestizaje cultural entre la población europea e indígena, sino una colonización que empleó como primera medida la esclavización de la mano de obra indígena y luego la negra, que conllevó la supresión de sus primitivos rasgos culturales y la obligatoria aceptación de la cultura lusitana, que se manifiesta en las artes y las letras a lo largo de ese siglo en la colonia; es decir, que el proceso intelectual proviene de la metrópoli, pero los materiales y mano de obra son locales (Priore y Venâncio, 2001: 126-133) . El proceso esclavista se vio reforzado desde la década de 1720, por la evidencia del inmenso tesoro mineral que guardaba la región de Minas Gerais, intensificándose el tráfico negrero desde las costas de Guinea y de Angola, alentado por la "buena adaptación" de los africanos a los trabajos rudos (Wehling y Wehling, 1999: 200-201). Pero la presencia negra, sí conoció un progresivo proceso de mestizaje y sincretismo, como ha estudiado Renata Homem, que afirma que el lenguaje de lo sincrético fue ampliamente reconocido por la más reciente investigación y escritura historiográfica como el elemento fundacional de la cultura brasileña a partir de los estudios sobre el siglo XVIII, sucediendo a las investigaciones sobre la mera expansión colonial portuguesa, que aún no contemplaba masivamente la presencia de la población negra (2014: 25-39). De hecho, podemos considerar que la visibilidad absoluta de la negritud, su cultura e impacto en la conformación del Brasil solo fue nítidamente apreciada por los ojos de los viajeros europeos del siglo XIX, tal y como revelan sus álbumes de viajes. En el siglo XX, el antropólogo Gilberto Freyre en su monumental obra Casa-Grande e Senzala (primera edición de 1933) decía que "en todo lo que es una expresión sincera de la vida, traemos casi todos la marca de la influencia negra" (1995: 283).

Para los portugueses, Brasil era mayoritariamente un fragmento de Portugal en América del Sur cuya función exclusiva era proporcionar materias primas para fomentar su comercio y prestigio en Europa. Las obras de arte debían exponer con toda claridad la manera lusitana de vivir la fe, el prestigio de la clase dominante y la fiesta como vehículo de transmisión social de las grandes verdades del pensamiento moderno. Por todo ello, el arte brasileño, cara visual y perceptible de los procesos históricos, es claramente deudor del tardobarroco italiano, pero llegado a través de Portugal gracias al entusiasta apoyo de los reyes d. João V y luego por d. José I, con el visto bueno de su plenipotenciario ministro, el marqués de Pombal y aceptado en la colonia como la única manifestación cultural posible porque venía de la metrópoli. Ahora bien; ese origen tardobarroco italiano se transformó por la esencia antropológica y cultural brasileña en un elemento de identidad, es decir, que no responde a una fase de continuación, como en Italia (pues en Brasil no se puede identificar al siglo XVII como un tiempo plenamente barroco, pues faltaban los soportes intelectuales y de mecenazgo al tratarse de una sociedad en construcción), sino de madurez. La riqueza aurífera de Minas y su salida a través de Río favoreció que, en 1763, bajo el virreinato y gobierno general de d. Antônio Álvares da Cunha, se transfiriese la sede del gobierno del Brasil desde Salvador de Bahía a la ciudad, albergando, consecuentemente, todos los poderes de la colonia. Y como dice el dicho popular, un rey no tiene solo que serlo, sino parecerlo.

Por todo ello, la segunda mitad del siglo XVIII verá cómo una ciudad que lentamente se había ido reponiendo de la devastación causada por Duguy-Trouin en 1711, debía ahora reactivarse, reformar los antiguos cuarteles y residencias de Estado, las casas de los escasos nobles y funcionarios del gobierno general, así como las de los burgueses residentes en la ciudad. De los edificios civiles levantados en esa época pocos sobrevivieron. Tras la llegada de d. João VI se decidió adecuar la capital al gusto de las cortes europeas del siglo XIX, triunfando el clasicismo como corriente estética internacional.

Los templos cariocas de la segunda mitad del siglo XVIII y comienzos del siglo XIX fueron concebidos como grandes escenarios del milagro. La hojarasca tallada en madera, o yesería, de los retablos, que en muchas ocasiones estaban dorados, las columnas salomónicas, las flores desplegadas entre los nichos, paneles, bóvedas y tribunas que albergaban escenas de 
lo sagrado, todo, en definitiva, buscaba impresionar, imponer, seducir. Muchos de los templos decorados ese siglo fomentaban la piadosa contemplación de los santos de Dios, modelos de perfección, que nos conducen a la veneración del Santísimo, situado en el nicho central del retablo mayor al que se accede por una escala, alusión directa a la Escala de Jacob (Génesis, 28: 11-28), aunque también el retablo podía estar presidido por Jesús Crucificado; por cierto, que esa escala, como elemento compositivo del retablo, es propia del mundo religioso portugués y brasileño, divergiendo de la tradición española. Río se transformará de esta manera en un nuevo teatro de la fe, a la manera plenamente barroca ien pleno siglo XIX! Como fe y poder van íntimamente ligados en el Estado Moderno (en este caso, del imperio), el esplendor religioso es resultado de la fidelidad y magnanimidad del emperador, de ahí la solicitud de dineros para la construcción y ornatos de los templos fluminenses dirigidos a la corona.

Son muchos los relatos de los viajeros de nacionalidad francesa o inglesa, y de otros países, que incluyen en sus memorias la estancia en el puerto carioca. Nos llaman especialmente la atención los escritos por los ingleses. Aunque tradicionales aliados del rey de Portugal, su recelo hacia la Iglesia romana hace que sus testimonios no estén inducidos por la mentalidad religiosa católica y las descripciones de Río sean frescas y reflexivas. Es el caso del informe de Lord George Macartney (1737-1806), que formó parte de una expedición político-diplomática del Reino Unido a China, que cuando pasó en otoño de 1792 por la ciudad, dejó un relato extenso sobre ella. Con respecto al arte religioso, llama la atención el siguiente párrafo:

"El objetivo de la conquista del Brasil era, según se pregonaba ostensivamente, la conversión de los naturales a la religión cristiana. Por esta razón, las iglesias y conventos locales fueron ricamente construidos y decorados. Pero, sea cual fuere en el celo del clero por ejecutar ese proyecto, la verdad es que hoy en dia ese celo ha dado lugar a la indolencia y al gusto por el lujo. Esos santos hombres, aunque conserven la apariencia de devoción, respetando de una manera extraordinariamente puntual las ceremonias religiosas que impresionan al vulgo, dejan mucho que desear en lo que se refiere a la moral y a las buenas costumbres. La influencia de tales religiosos, con todo, es muy fuerte, aunque la población no alimente temor con relación a ellos, pues el Tribunal de la Inquisición no se estableció en Brasil" (França, 1999: 223-224)․․

Esa riqueza de construcción y decoración conocida por Lord Macartney es de gusto barroco, pues en las fechas en que viajó se había concluido el ornamento de lugares tan destacados como el monasterio de São Bento o la capilla de los terciarios franciscanos de la ciudad, de exaltación decorativa barroca, contraria en todo al gusto británico hacia 1792 con un arraigado gusto clasicista. Justamente por ello, entender la estética barroca como una forma de expresión colonial, reflejada en otros párrafos de la misma memoria, es en sí un dato excepcional para comprender el gusto en la ciudad al borde del siglo XIX.

De todas formas, suponer que el Barroco en Río, como en todo Brasil, es consecuencia directa de la evolución de los estilos artísticos es un error frecuente en la historiografía, al asimilar la evolución de las artes a la cronología de los países católicos europeos. Efectivamente, en Brasil han existido escuelas de historiadores del arte, que se remontan a las décadas de $1950^{2}$, que buscan la aceptación por la comunidad científica internacional del arte colonial, e

1 Incluido en la antología de textos y fuentes del periodo colonial en Río de Janeiro complicado por Jean França. Traducción de nuestra autoría. Hemos traducido las fuentes y citas de esta publicación, de lengua portuguesa a española, para hacerlas más comprensibles.

2 Naturalmente, el origen del debate en la historiografía se halla en la publicación en París en 1956 de L'Architecture religieuse baroque au Brésil, que impulsó definitivamente los estudios del arte colonial brasileño, no solo en el país, sino en toda Europa. A su empeño se debió la formación de una escuela que ha buscado el conocimiento y adaptación del lenguaje formal artístico europeo al arte brasileño, como se aprecia en la introducción del libro O Rococó religioso no Brasil (2003) de Myriam Andrade Ribeiro de Oliveira. No obstante, Ramón Gutiérrez, en la publicación de Arquitectura y urbanismo en Iberoamérica (1983), ya observaba que "la comprensión del fenómeno colonial, y particularmente la interpretación del barroco americano, ha girado sobre premisas culturales preferentemente eurocéntricas marginando las valoraciones de nuestra propia realidad" (Gutiérrez, 1983: 11). Naturalmente, ambas perspectivas nacieron en su contexto histórico e historiográfico y han evolucionado en la escritura de los autores mencionados y con numerosas adhesiones de otros historiadores a lo largo de las décadas. No es el objetivo de este artículo un debate historiográfico, pero sí queremos dejar constancia de que en el caso brasileño, extendido bajo nuestra perspectiva para toda América, los factores intrínsecos de la evolución histórica, cultural, política y religiosa -incluido el sincretismo-, hacen del arte brasileño un fenómeno único e irrepetible. Por ello, el debate historiográfico que proponemos aquí supera cualquier planteamiento bajo la perspectiva de la historia de los estilos o lenguajes para adentrarse en la vivencia del ser humano sobre cualquier tipo de discurso o instrucción recibida desde la metrópoli, lo que justifica el singular florecimiento del gusto barroco en el siglo XIX. 
incluso del siglo XIX, intentando ajustar los criterios estilísticos y cronológicos brasileños al arte barroco europeo. Pero creemos firmemente que la originalidad del barroco brasileño se haya, justamente, en que no puede encajarse en esos parámetros bajo ninguna hipótesis. Sin embargo, desde mediados de la década de 2000 se suceden muchos trabajos de investigación, trabajos de fin de máster (disertação de mestrado) y tesis doctorales (disertação de doutorado), que apuntan hacia una visión menos eurocéntrica y más realista sobre el significado de las manifestaciones artísticas del Brasil. De hecho, es nuestra opinión como brasilianista que al escribir sobre el contexto del Barroco, debe interpretarse como una actitud cultural y social que trasciende las formas y su sentido intrínseco, como expresión de la fe o del poder, tal y como lo entendemos en Europa, y especialmente en España o Portugal, para evolucionar hacia un concepto transcendental de la vida que incluye cualquier mestizaje, sincretismo cultural o religioso, manifestado en madera tallada, dorada y/o policromada, imágenes vestideras (de roca) o de talla y con rocallas, traspasando con holgura la frontera de 1800 . En este sentido, afirmamos que, pese a la arribada de la cultura clasicista, una parte del Brasil y de la ciudad de Río de Janeiro, en pleno siglo XIX, no crearía arte barroco, sino que viviría inmerso en una vida barroca.

Margareth Pereira, analizando el significado ese gusto como estructura sustancial de la identidad carioca, señala que:

"Es cierto que el universo cerrado, retórico y tópico de las cúpulas, de los palacios de las hogueras, de los mártires, de los príncipes y de los cardenales, engendrado en el periodo Barroco, busca afirmar la autoridad del dogma, del rey, de la ley. Mientras tanto, la manipulación de estas inscripciones visibles, por su exceso, tal vez manifieste sobre todo la intuición radical y sin salida de la atopia de la condición humana, revelada de forma inexorable en el horizonte abierto a la relación y al orden - a la voluntad y al arbitrio- de la experiencia americana" (2000: 313$)$.

Estamos de acuerdo con la autora en el hecho de que las manifestaciones que analizamos en este trabajo son una atopia, es decir, que son ejemplos de una hipersensibilidad al sentido retórico del poder que las nuevas clases dominantes asentadas en la ciudad desde que se transformó en capital en 1763, que eran de origen popular y sin raíces ni conexiones con la hidalguía portuguesa, buscaban en la cultura barroca un marco de representación a la altura de sus flamantes cargos. Así, la retórica barroca, lejos de los lenguajes literarios o artísticos, era un cauce por el que el poder como sensación placentera y novedosa, pudiese fluir sobre una base tan endeble como el sistema esclavista. Este análisis está de acuerdo con la perspectiva decolonial, pues percibimos las manifestaciones artísticas de la ciudad, no desde la estructuración evolutiva de los estilos, sino desde la realidad objetiva que nos relegan tanto las fuentes documentales como las propias obras de arte que han pervivido y evidencian este proceso creativo. A pesar de que adjetivemos estas obras del siglo XIX como barrocas, no lo hacemos pensando en un lenguaje artístico proveniente de Europa y adaptado al Brasil, un proceso construido a lo largo del siglo XX por la historiografía brasileña y analizado por Márcia Chuva, quien señala que "el concepto de barroco, bastante difuso, siempre fue perseguido como origen mítico de nuestra nacionalidad" (2003: 329). Al contrario, cuando estudiamos estas obras, lo que pretendemos es identificar al barroco como un signo divergente de la realidad artística europea al ser profundamente singular e irreconocible en una interpretación canónica, causando, justamente por ello, el asombro de los extranjeros que pasaron por Río.

El ennoblecimiento de esta nueva clase social carioca gracias a los títulos repartidos por d. João VI al llegar a su nueva corte tropical para agradecer o pagar servicios a la corona, una política continuada por su hijo el emperador d. Pedro I tras la independencia, fortaleció un lenguaje visual con los gustos de la vieja nobleza terrateniente de Portugal, lo que no dejaba de ser una ficción o una mascarada. Dicho de otro modo, las formas barrocas fortificadas y extendidas por la cultura arquitectónica y visual del siglo XIX, no solo suponían el éxito, o simplemente, la costumbre, de un discurso formal, sino que invitaba a un clima versallesco como base de la sociedad elitista del imperio brasileño. Esa cultura y hábitos, tan trasnochados para los entornos refinados europeos que habían vivido intensamente las 
transformaciones políticas tras la Revolución Francesa, resultaban exóticos y fascinantes a ojos de los viajeros, pero eran también novedosos para la nueva aristocracia brasileña, a pesar de que como señala Kristen Schultz, buena parte de esa misma élite condenaba la esclavitud por ser una señal de atraso, ligada al colonialismo recién abandonado, una causa onerosa con escasas contrapartidas; en definitiva, un lastre (2008: 182). Pero la decoración de los edificios religiosos y civiles construidos o concluidos a lo largo del siglo XIX, parecen desdecir esa apreciación.

Fue común en los templos levantados en los años finales del siglo XVIII la mezcla del estilo arquitectónico vignolesco heredado del primer arte brasileño traído por los jesuitas (iglesia de la Compañía en Salvador de Bahía, hoy catedral), con la concepción barroca del espacio en consonancia con la forma de vida de la ciudad. Sin embargo, las soluciones del siglo XVI, unidas a las tendencias clasicistas lusitanas del tiempo pombalino, resultaron frías a la sociedad local, acostumbrada a la emotividad barroca. Por ello, a comienzos del siglo XIX, viviremos una realidad singular: la armazón arquitectónica clasicista en los edificios de nueva construcción se verá engalanada interiormente de ornamentación de tradición barroca, para adaptarse mejor a la sociedad brasileña.

\section{EL COMBATE ENTRE BARROCO Y CLASICISMO EN EL ESPACIO CARIOCA.}

En 1808 llegó el futuro d. João VI de Portugal a Río de Janeiro (en calidad de prínciperegente por invalidez de su madre, la reina $\mathrm{d}^{\mathrm{a}}$. María I), acompañado de la familia real y los miembros más destacados de la corte, en compensación a la invasión del territorio portugués por las fuerzas de Napoleón Bonaparte. La pequeña pero importantísima ciudad colonial se transformó en un tiempo record en la corte del antiguo Reino de Portugal, siendo su capital entre el 16 de diciembre de 1815 hasta el retorno de d. João VI a Lisboa en 1821. A lo largo de esos años se creó una verdadera corte que necesitaba transformaciones. En palabras de la citada Kirsten Schultz:

«La transformación de Río de Janeiro tras la llegada del príncipe regente se basó en la búsqueda de la semejanza de proyectar una imagen del poder real en nociones de semejanza en la relación existente entre el orden, la lucidez y el progreso» (2008: 158).

Dicho de otro modo, la llegada de la corte no buscó en momento alguno el conocimiento de la cultura brasileña y la adopción del modo de vida de la colonia. Pretendía justamente lo contrario: reforzar, si era posible, la forma de vida cortesana dejada en Lisboa, mucho más grandiosa. Por ello d. João VI (proclamado rey tras la muerte de su madre en 1816), decidió convertir la ciudad en un verdadero escenario del poder a la manera europea. Para ello fundó importantísimas instituciones culturales, como la Biblioteca Nacional (1814), el Jardín Botánico, varias instituciones de enseñanza, como la Escola Real de Ciências, Artes e Ofícios (1816), además de reformar toda la hacienda pública y ordenar un nuevo planeamiento urbano para adecuar una ciudad "de otro tiempo" a la idea de "modernidad" surgida de la Ilustración e incentivada, a su vez, por las reformas y el propio concepto de ciudad debatido en Inglaterra; estas ideas, bien analizadas por Vera Tostes (2008: 41-47), lleva a concluir que Río personificó las transformaciones ocurridas en Brasil tras la Independencia.

De hecho, la primera decisión relevante fue invitar a Río en 1815 a una comisión de arquitectos y artistas franceses, muchos de ellos vinculados hasta entonces con los círculos napoleónicos, dirigidos por Joachim Lebreton y formada por Jean-Baptiste Debret, pintor; NicolasAntoine Taunay, pintor de historia y paisajes; Grandjean de Montigny, arquitecto; Auguste-Marie Taunay, escultor, y al menos seis artistas más. Todos ellos, conocidos historiográficamente como la Missão Artística Francesa, recibieron el encargo de organizar la Escuela Real de Ciencias y Artes (de donde nacería la Academia Imperial de Belas Artes) e introducir un nuevo gusto cultural y artístico en la corte carioca: el Neoclasicismo (Xexéo: 2003, 67-71).

Esta comisión, a la que se sumaban muchos miembros del Senado da Câmara do Rio de Janeiro, de origen portugués, que tenían en sus retinas la modernización de Lisboa en las décadas de 1760-1770 bajo la mano de hierro del marqués de Pombal, auspiciaban ese tipo de cambios, no solo en las cuestiones estéticas, sino también en la propia forma de pensar la 


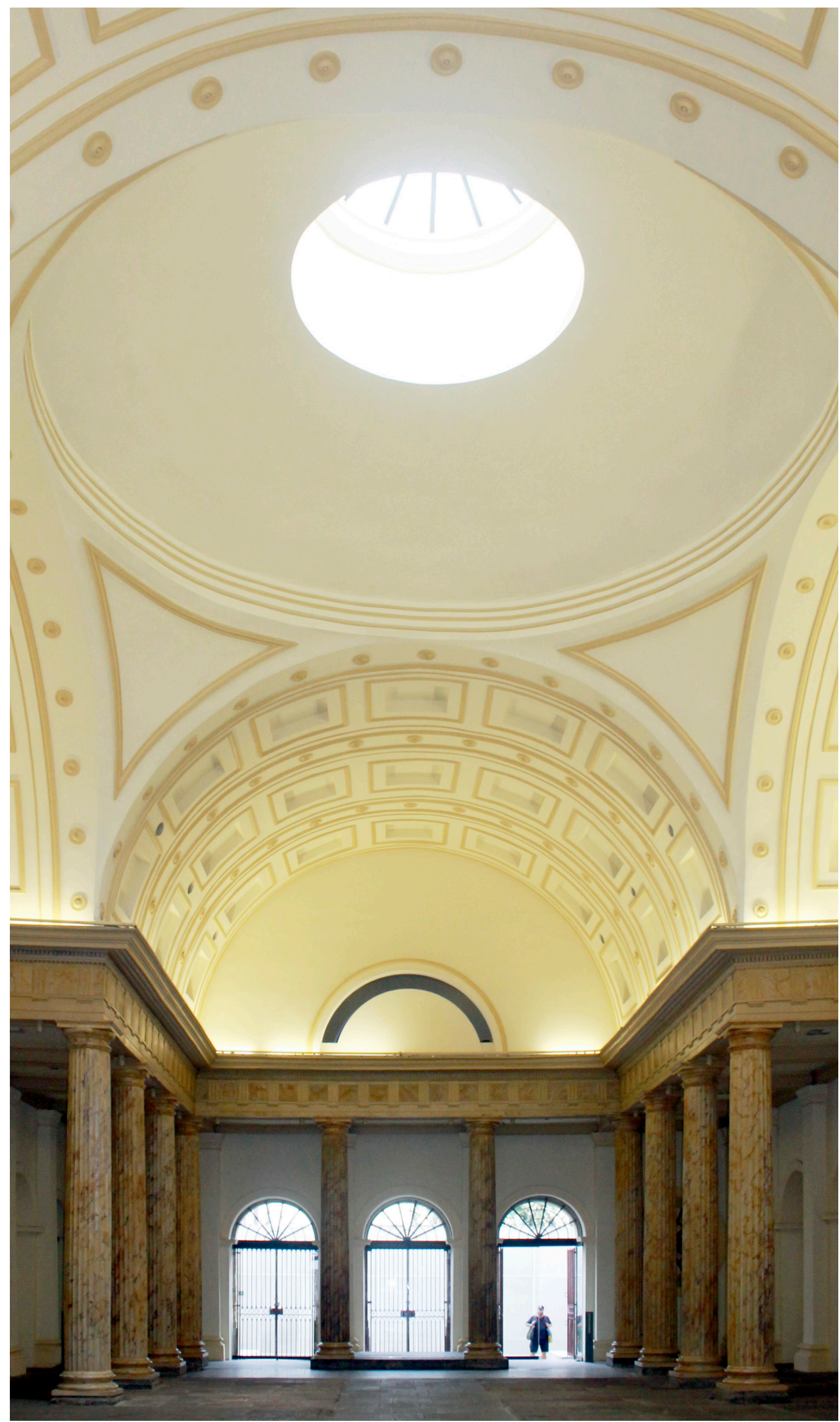

Figura 1. Casa França Brasil. Granjean de Montigny. C. 1820. Rio de Janeiro. Fotografía del autor 
ciudad, exigiendo progresivas mejoras tanto en el trazado en cuadrícula de las nuevas áreas a ser construidas como en el saneamiento del perímetro urbano, carente de una normativa básica de higiene (Carvalho, 2008: 74-103).

La cuestión es si podemos aceptar que la llegada de la corte a Río, la creación de instituciones o la construcción de edificios, supuso la asunción de un nuevo gusto, ahora de corte neoclásico. Ejemplos tempranos de ello son la adaptación de la vieja residencia de los gobernadores como palacio imperial a comienzos del siglo XIX, la construcción de la aduana de la ciudad, hoy Casa França-Brasil, proyectada por Grandjean de Montigny durante la década de 1820, cuyo espacio central refleja la gran arquitectura clásica -aprendida en los tratados clásicos y neoclásicos- con una bóveda rebajada y abierta por un lucernario, mientras los arcos que la sustentan son casetonados. Más tardíamente, destaca la construcción de la nueva Santa Casa de Misericórdia, un gran centro hospitalario, con una notoria portería de proporciones clásicas. Podríamos citar otros muchos edificios para ejemplificar el cambio que introdujo la corte, pero los mencionados, por sí solos, que apuntan los cambios que pretendían introducirse en la capital, son bien conocidos y divulgados en textos científicos y divulgativos de historia del arte, como indica Hoirisch, Salgado y Ribeiro, quienes destacan que el neoclásico es el medio por el que la sociedad "expresaba su idea de progreso, no siendo más la ciudad patrimonio del clero y de las familias ricas" (2009: 70). Además, la aportación especial de Grandjean de Montigny ha justificado un proyecto de investigación que arroja interesantes resultados sobre la introducción del neoclasicismo y su evolución en la ciudad, que, a pesar de su trascendencia, no cuenta con suficientes estudios en la historiografía del arte (dos Santos, dos Santos, da Silva y Peixoto, 2016: 69).

Bien, sabemos que todo esto fue fomentado por la corte y por el propio gobierno de la ciudad, pero ¿qué sentían los cariocas ante estas novedades, impuestas en la ciudad de manera un tanto forzosa? La respuesta se halla en los edificios decimonónicos más vinculados a los grupos de poder locales que a la presión cortesana. La sociedad local ya había "tolerado" desde finales del siglo XVIII la introducción de elementos clasicistas entre tanta ornamentación barroca. Un caso ejemplar para entender la convivencia de ambos estilos es la nueva fábrica de la iglesia de Santa Cruz dos Militares. La hermandad de los soldados de la guarnición de Río contaba con una capilla desde 1611, que sufrió numerosas transformaciones; pero en 1776 se decidió levantar un nuevo edificio y se aprobó el proyecto del ingeniero militar José Custódio de Sá Faria, quien planteó un alzado tan clasicista que casi nos remite a los modelos albertianos y, como no, vignolescos (Gutiérrez, 1992: 151-152); sin embargo, el resultado debió parecer poco piadoso porque la hermandad se planteó, ya en pleno siglo XIX, añadir un ornato plagado de molduras de estuco de rocallas y formas vegetales que, como en todo el barroco, reforzase la idea del templo como escenario del milagro. Y las adaptaciones estéticas sufridas por este edificio nos ponen en guardia para entender la metamorfosis del clasicismo al barroquismo que experimentaría el arte que venía de las antiguas élites coloniales que, hasta cierto punto, chocaba con las aspiraciones cortesanas. Esto último se manifiesta también en cómo se recaudaban los dineros para esas nuevas obras; es interesante aproximarnos a los mecanismos de subvención para ver más de cerca la mentalidad social y su relación con la jefatura del poder.

\section{LA CORTE Y LAS SUBVENCIONES AL GUSTO BARROCO EN EL SIGLO XIX.}

Más allá de las cuestiones estéticas, también hemos de valorar fuentes específicas que revelan los motivos por los que pervivió el gusto barroco. Costear las obras en los templos cariocas exigía verdaderas fortunas, por lo que había que recurrir a fondos privados o donaciones de la élite de la ciudad, pero también a fondos públicos de la corona. En la lectura de las solicitudes se aprecian las fórmulas diplomáticas donde perduran los resabios del estado moderno en cuanto a la función que éste debe cumplir con respecto a las obras de nueva edificación, así como el propio sistema de financiación.

La actual catedral de San Juan Bautista de Niterói, ciudad que se yergue frente a Río, al otro lado de la bahía de Guanabara, fue construida en el siglo XVII, pero hacia 1800 amenazaba ruina. Por ello, los hermanos del Santísimo Sacramento de ese templo, solicitan: "Que desean levantar una nueva iglesia matriz dedicada a san Juan Bautista que está en su trono en el centro 
de la sobredicha villa, por hallarse a esta hora la que existe muy vieja e indecente y desviada de la misma villa y muy humildemente Por Vuestra Majestad, que se digne hacerle merced de concederle la licencia necesaria". ${ }^{3}$

Habituados a analizar series documentales brasileñas, con las que estamos muy familiarizados, podemos afirmar que desde el siglo XVII esa fórmula diplomática no fue modificada hasta 1822, pero tampoco lo hizo durante el imperio; es decir, que la costumbre de que los monarcas, y desde 1822 los emperadores, permitiesen la financiación pública de las obras religiosas, es una realidad derivada del real padroado portugués. Dicho de otro modo, que se percibe como un beneficio de la corona la obligación de mantener a la Iglesia, un privilegio reconocido por Roma desde finales del siglo XV, ahora extrapolado al sistema del imperio brasileño, como se aprecia en la solicitud de este templo. ${ }^{4}$

Un caso similar apreciamos entre los hermanos del Santísimo Sacramento de São José do Ribamar, Recife (Pernambuco), que en 1845:

“(...) Por el celo e interés que V.M. ha manifestado constantemente por la conservación y esplendor de la Religión del Estado, y todavía más, llevada por la necesidad de tener frente a si al Protector cuyo nombre y cuya sombra sirve de amparo a su asociación cristiana solo en sus comienzos y un Benefactor cuya munificencia aliente el fervor de aquellos que tienen tomado sobre sí la dispendiosa tarea de erigir y decorar con la precisa decencia la indispensable morada que Dios debe habitar entre los hombres (...) Venimos a pedir a V.M.I. no solo la gracia de aceptar el Protectorado sobre dicha Hermandad, sino aún el socorro que la beneficiosa devoción de V.M.I. se digne liberalizar (....)".5

Es decir, que se vincula en 1845 el éxito de la construcción del templo con el patrocinio del emperador, sin que se hubiese alterado el más alto patrocinio heredado del tiempo colonial; de hecho, un término que parece insignificante, pero al que damos mucho valor, es decorar, no solo construir o edificar. Ese decorar está íntimamente relacionado con el sentido barroco del decoro, pues se acepta en pleno siglo XIX que la mejor representación escenográfica del trono divino y del trono humano del emperador, es un espacio barroquizado por lo que implica de magnificencia.

En Río de Janeiro, la hermandad del Santísimo Sacramento de la catedral de San Sebastián, que por esas mismas fechas se encontraba instalada en la iglesia ruinosa de Nuestra Señora del Rosario, ${ }^{6}$ pedía al emperador que permitiese la concesión de ocho loterías para que con sus beneficios se iniciase la construcción de un templo específico para esta hermandad, que sería finalmente edificado y que es uno de los que abordaremos en este estudio.

$\mathrm{Al}$ emperador se le requiere:

"(...) Y porque la obra de la iglesia se haya bastantemente atrasada por falta de rendimientos para ella, para ello [los hermanos] recurren a V.M. se digne concederles la gracia de hacer a los suplicantes ocho loterías en el espacio de cuatro años por medio del plan que se adjunta, siguiendo los suplicantes las órdenes establecidas para con el resto de las loterías, que $V$. M. ha concedido, para con los rendimientos de ella poder los suplicantes con más facilidades progresar en la factura y obra de la nueva iglesia (...)". ${ }^{7}$

$\mathrm{Si}$ consideramos estos testimonios, que son meros ejemplos de los procedimientos

\footnotetext{
3 Ofício dos membros das Irmandades de São João Baptista e do Santíssimo Sacramento da Vila Real de Praia Grande [Niterói], 1820, Biblioteca Nacional do Rio de Janeiro (Brasil), Divisão de Manuscritos (II-34, 20, 8), 1 fol. La traducción es de nuestra autoría.

4 La iglesia se construyó finalmente entre 1819 y 1831. Sin embargo, entre 1885 y 1886 se procedió a construir un nuevo templo, el actual, que ya fue dedicado a la Inmaculada. Obtenemos esta información de la ficha catálogo de la Secretaria de Estado de Cultura do Governo do Rio de Janeiro: http://mapadecultura.rj.gov.br/manchete/igreja-de-nossa-senhora-daconceicao. Consultado el 26 de junio de 2018.

5 Requerimento da Irmandade do Santíssimo Sacramento da freguesia de São José de Ribamar, solicitando a S.M.I. se digne aceitar protetorado da nova Yrmandade, Recife, 1845, Biblioteca Nacional do Rio de Janeiro (Brasil), Divisão de Manuscritos (II-33, 4, 31), fols. 1-1v. La traducción es de nuestra autoría.

6 La catedral de San Sebastián, a comienzos del siglo XIX se hallaba en muy mal estado de conservación. Por eso, el culto fue llevado al templo del Rosario de los hermanos negros (esclavos y libres), pero que, a su vez, también amenazaba ruina. De ahí que la hermandad del Santísimo, de hermanos blancos, desease una nueva edificación específica para ella con el fin de mantener el culto.

7 Ofício do Provedor e Mezários da Irmandade do Santíssimo Sacramento [da antiga Sé do Rio de Janeiro] pedindo a S.A.R. a concessão de oito loterias no espaço de quatro anos, sin fecha, hacia 1840, Biblioteca Nacional do Rio de Janeiro (Brasil), Divisão de Manuscritos (II- 34, 29, 14), fol 1r. La traducción es de nuestra autoría.
} 
administrativos para para construir y/u ornar los templos, podemos concluir que los patrones estéticos del gusto, que continúan métodos técnicos y estilísticos del barroco, no son más que un elemento que se suma a una comprensión global del arte religioso, aún vinculado al Estado, donde la magnificencia es consecuencia de la comprensión del medio artístico, literario o musical como parte del sentido de la Historia, cauce natural por el que fluye la construcción de una sociedad, perfectamente estratificada y sin una necesidad expresa de cambios.

La llegada a Río de Janeiro en 1816 de la Missão Artística Francesa, supuso la arribada de la estética neoclásica, como ya hemos señalado. Sin embargo, ese sentir artístico, al no estar asociado a un proceso revolucionario como en Francia, solo implicó unos cambios significativos en las modas de la corte, en los gustos, en las preferencias, pero no en el sentido más profundo del arte religioso o en la expresión de las élites hasta la proclamación de la República en 1889. El gusto barroco siguió siendo la revelación más sublime del esplendor; la adopción de esquemas clasicistas no alteró en ningún momento el sentido pleno del arte. De hecho, Roberto Conduru (2003: 144-145), cuando estudió la obra arquitectónica de Grandjean de Montigny (París, 1776-Río de Janeiro, 1850), señala que lo encontrado al desembarcar en 1816, fue el empleo de fórmulas clasicistas en algunos edificios civiles y religiosos, pero no una cultura realmente neoclásica, que, en el fondo, no llegó a impregnar como nuevo lenguaje de la comunicación el gusto brasileño más allá del entorno cortesano. La documentación frecuente hasta la proclamación de la República confirma, por tanto, las pautas de subvención provenientes del mundo colonial; la Missão solo supuso una división de aguas; a un lado, la tradición de la estética barroca en el Ochocientos, al otro, casos puntuales de edificaciones y decoraciones (que incluyen pinturas al lienzo, retratos, esculturas, etc, de gusto moderno) cuyo auspicio dependía no de solicitudes de grupos gremiales, sino de decisiones directas de la corona para una mejor escenificación de los nuevos patrones estéticos, pero con escasa repercusión fuera de la corte.

\section{LA DECORACIÓN BARROCA COMO PATRÓN DE GUSTO EN LOS TEMPLOS CARIOCAS DEL SIGLO XIX.}

Para ejemplificar todos los argumentos expuestos, hemos escogido algunos templos que, en su mayoría, fueron concluidos en los años centrales del siglo con ornatos de yeserías o madera en las cornisas formadas por hojarascas, con capiteles y columnas de inspiración claramente barroca, junto a frontones curvilíneos y cornisas sinuosas que, de hecho, combatían y contrariaban la fuerza teórica clasicista impulsada por la corte que, en realidad, jugaba a dos bandas. Pero más allá de todo lo que hemos apuntado en cuanto al patrocinio y los criterios de gusto, también es cierto que los artistas cariocas continuaban un sistema de trabajo y organización gremial que hunde sus raíces en el Portugal medieval, al igual que en España, pues es sabido y divulgado que el sistema de organización y defensa de los escasos beneficios profesionales estaba guiado en Río por la agremiación en torno a las hermandades religiosas (Martins, 2012: 8-9).

Apreciamos todo lo señalado en el caso de muchos templos, como en São José o la capilla de Nossa Senhora do Terço, ambas en el centro de Río. La primera responde al esquema y tipología de planta de salón de influencia jesuítica; la ornamentación bajo el signo clasicista debió parecer muy pobre, pues en las reformas y ampliaciones acaecidas en las décadas finales del siglo XVIII y primera mitad del siglo XIX se añadió una decoración de estucos, imitando el aspecto de otras iglesias talladas en madera y doradas en la ciudad, como la del monasterio benedictino o de la capilla de terciarios franciscanos. De hecho, la reconstrucción de la pequeña ermita de São José, fundada hacia 1751, fue ejecutada en función del proyecto presentado por el ingeniero Félix José de Sousa y luego por el arquitecto de la casa real, João da Silva Muniz; la decoración en madera y estucos corrió a cargo de Simão José de Nazareth, discípulo del gran artista de transición entre el Barroco y el clasicismo, Mestre Valentim, ejecutándose la obra entre 1807-1824 (Bazin, 1982: 162). Es decir, que, aunque se mantuviese la tipología de planta de salón con desarrollo de la capilla mayor, las tribunas abiertas a la misma y decoración barroca con frontones curvilíneos partidos para permitir la floración de ornatos, etc. (Czajkowski, 2000: 63), implica la barroquización del templo clasicista en pleno siglo XIX, lo que se percibe, en el entorno de los patrocinadores eclesiásticos y parte de la sociedad, como un avance que sublima el esplendor decorativo por encima de cualquier otro factor. 


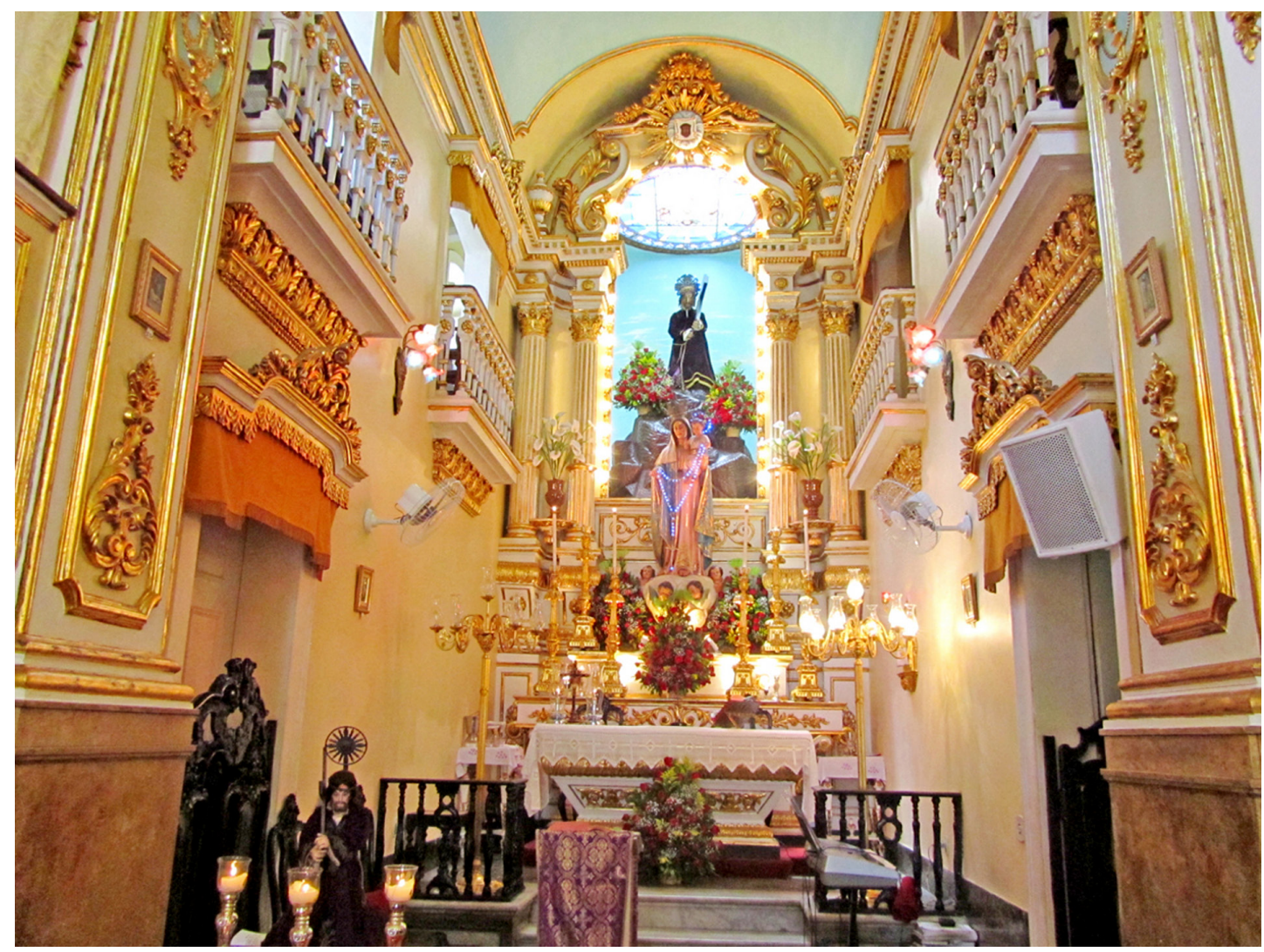

Figura 2. Decoración interior iglesia Nossa Senhora do Terço. Primera mitad del siglo XIX. Rio de Janeiro. Fotografía del autor

Es muy similar al caso de la capilla mencionada de Nossa Senhora do Terço, presidida por el Senhor dos Passos (Jesús Nazareno), que tiene la gracia de aquellas obras que parecen muy barrocas a pesar de ser extemporáneas para la cronología convencional de ese estilo, pues este espacio tan lusitanamente barroco, en su visión actual, fue iniciado en 1843 (Czajkowski, 2000: 69). Está muy presente el empleo de ornato de estucos por las tribunas, paneles vegetales que descienden las paredes y el uso de un arco de inspiración joanina, con volutas, en el retablo mayor, magnificando el mensaje religioso.

Lo mismo puede decirse de la iglesia del antiguo convento de carmelitas de Nossa Senhora do Carmo y la monumental capilla de Ordem Terceira de Nossa Senhora do Carmo; ambas edificaciones, que han sufrido intervenciones y añadidos desde la segunda mitad del siglo XVIII hasta el siglo XX, buscan en su arquitectura la espacialidad propia del mundo clásico, pero tanto la apertura de capillas laterales y sobre ellas, de tribunas, en el primero de los casos, y una cúpula en el crucero, en el segundo, nos remiten una y otra vez a soluciones barrocas. A ello se añade la talla espléndidamente barroca que orna ambos templos. En el caso de la iglesia del antiguo convento carmelita, al ser elevada al rango de capilla real en 1808, comenzó su verdadera transformación en un templo barroco con el objeto de ser visto como escenario del milagro y como espacio áulico. La decoración fue encargada al entallador y decorador carioca Inácio Ferreira Pinto (1765-1828) (Oliveira, 2008: 107-118), que dominaba las fórmulas decorativas barrocas con el uso y abuso de la hojarasca, la rocalla, la voluta, el empleo de tondos, guardamalletas, baldaquinos, columnas salomónicas y todo tipo de elementos arquitectónicos y guarniciones que reforzasen el sentido elevado y pomposo de la retórica barroca. En definitiva, que propagaba con eficacia las ideas presentes en los grabados de Guarino Guarini, aunque no ha podido demostrarse que conociese la obra teórica de este arquitecto, ingeniero y teórico italiano. Pero la historia constructiva de este templo asociado al gusto barroco continúa tras la proclamación de la República en 1889.

Para reasignar la popularidad del edificio disociándolo del imperio de los Bragança, se elevó a catedral de Río de Janeiro; la reforma inmediata del templo contempló abrir capillas laterales y el lenguaje visual escogido para la decoración, a pesar de las décadas transcurridas, 


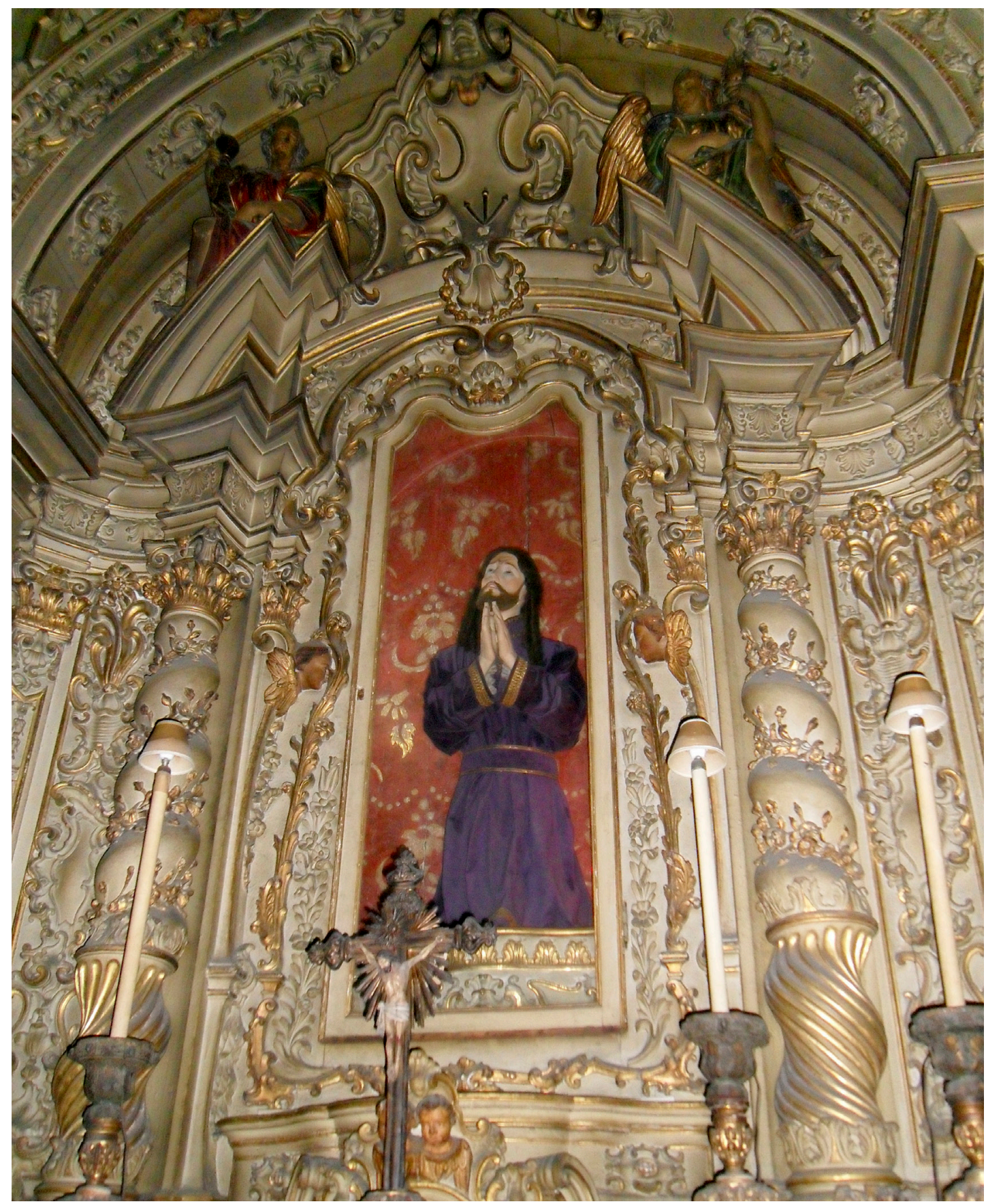

Figura 3. Altar lateral Iglesia Ordem Terceirado Carmo. Antônio de Pádua e Castro. C. 1840. Río de Janeiro. Fotografía del autor

volvió a ser el gusto y la estética barroca, inspirándose en la talla de Ferreira Pinto ejecutada en las tres primeras décadas del siglo. En este punto queremos indicar que son numerosos los historiadores del arte que trabajan la cultura brasileña que, ante la presencia del exceso del ornato, emplean el término rococó. A nuestro juicio, siguiendo los discursos bien cimentados en la historiografía producida mayoritariamente en Europa desde la década de 1980, el Rococó es justamente un arte tan aristocrático como burgués definido en Francia durante el siglo XVIII con un propósito laico, coqueto y muy distanciado de la grandiosidad barroca del Estado o la Religión. "Trivialidad y capricho son la primera definición que encontramos de Rococó: su propósito es crear objetos para satisfacer deseos tan caprichosos como fútiles: su justificación es simplemente el agrado, el complacer esos caprichos" (Seoane, 2000: 32). Así pues, el simple uso de la rocalla no fuerza que este elemento decorativo sea asimilable al sentir estético rococó. Al contrario: nada es más contrario a la solemnidad del culto litúrgico en el interior de los templos que el fluctuante gusto y moda del Rococó. A esto dedicaremos una referencia en nuestras conclusiones. 


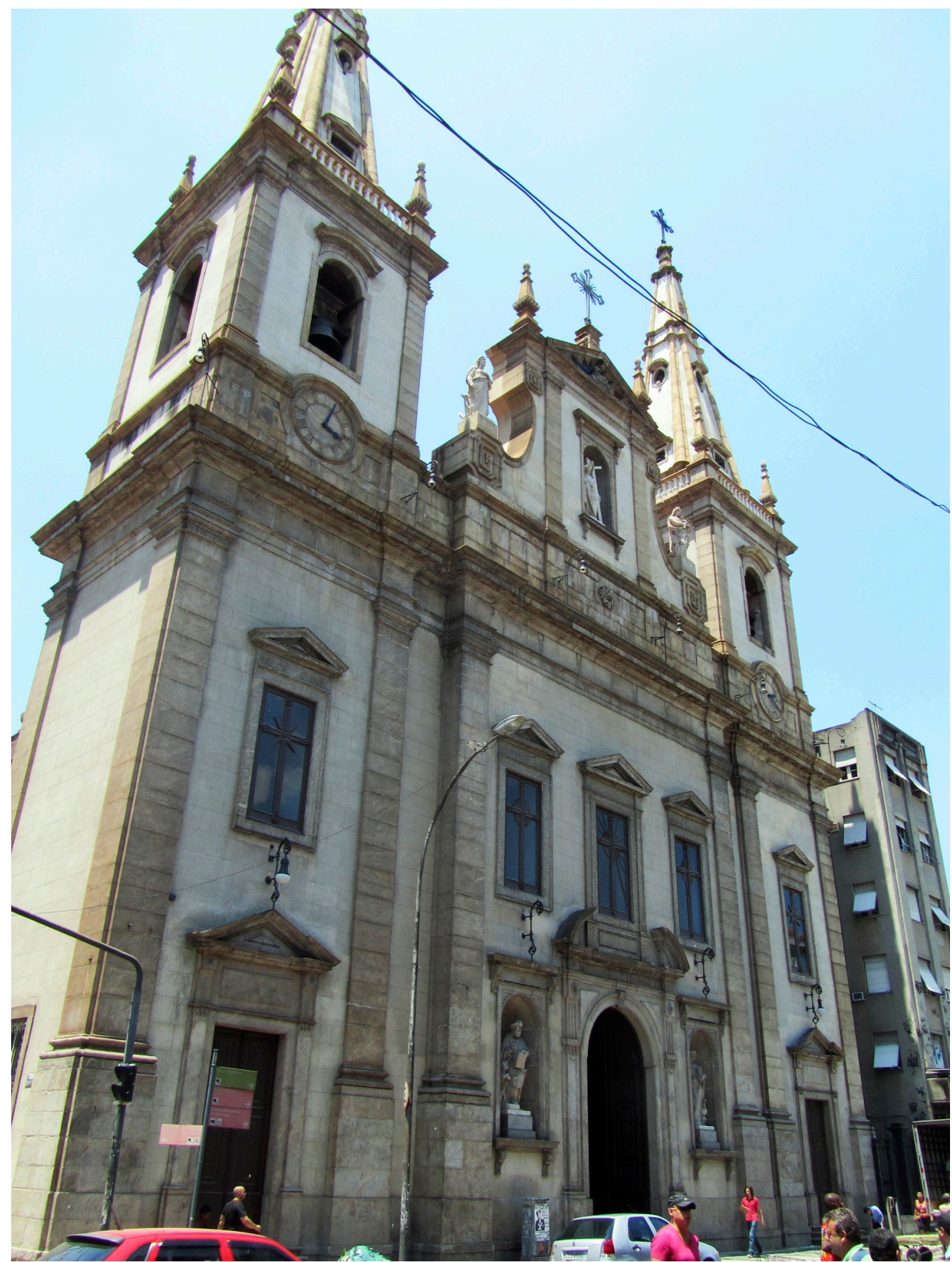

Figura 4. Fachada Iglesia Santíssimo Sacramento da Antiga Sé. C. 1840-1860. Río de Janeiro. Fotografía del autor

Por tanto, el Barroco como elección estética, fue transversal a todo el Ochocientos, de comienzo a fin, seguramente para reforzar el sentido religioso y social tan suntuoso de este lugar identificado con la propia historia de la ciudad.

En cuanto a la vecina iglesia de la Orden Tercera del Carmen, las superficies talladas se suceden desde las décadas finales del siglo XVIII; ya en el siglo XIX se decoran los paneles en las naves laterales, así como los retablos. En cuanto a esos trabajos, y tras el fallecimiento de Ferreira Pinto, su factura se debe a Antônio de Pádua e Castro (1804-1881) y su taller, probablemente iniciados en la década de 1840 (Czajkowski, 2000: 60) y cuyo estilo ha sido aproximado por Cybele Fernandes a una cierta influencia de las decoraciones francesas (en 


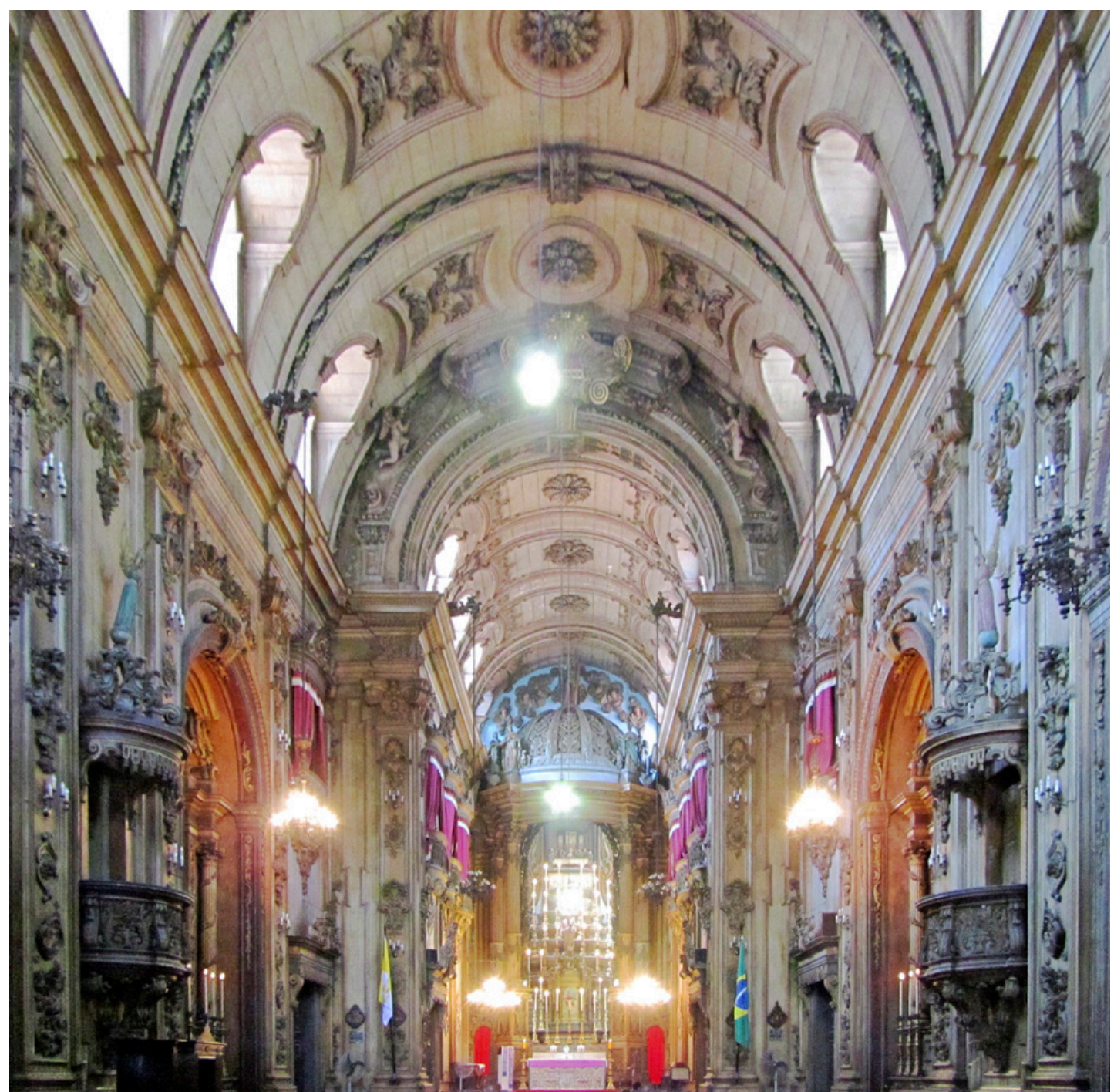

Figura 5. Decoración interior Iglesia Santissimo Sacramento da Antiga Sé. Atribuida a Antônio de Pádua e Castro. C. 1844. Río de Janeiro. Fotografía del autor

cuanto a los motivos de los paneles). ${ }^{8} \mathrm{Y}$ es curioso, porque el concepto ornamental del templo contrasta con las trazas arquitectónicas, que se alejan de la costumbre tradicional portuguesa de bóveda de cañón en la nave y la capilla mayor, para incorporar en esta última una cúpula, una opción italianizante que no modificó la elección de repertorios barrocos (Lustosa, 2008: 39-61). Es decir, que el curioso resultado final nos permite contemplar la estética barroca en un espacio presumiblemente clasicista.

Otro ejemplo notorio de edificios influidos por la nueva mentalidad de tendencia clasicista, pero de vivencia espiritual y adorno barroco, es la construcción de la fantástica iglesia del Santíssimo Sacramento da Antiga Sé, iniciada ya en el siglo XIX, pero inaugurada en 1859. Poco se conoce sobre el proyecto inicial; apenas que en él trabajó en sus comienzos el ingeniero João da Silva Muniz y pudo ser concluída por el maestro de obras José Bethencourt da Silva (Czajkowski, 2000: 69). En torno a la fecha en que se inician los trabajos, solo existe un documento de 1816 donde los hermanos del Santísimo Sacramento de la catedral -Antiga Sé-, solicitan al rey D. João VI la concesión de explotación de ocho loterias por espacio de cuatro años para recaudar fondos "[pues] ya con los diminutos réditos de la Hermandad, la limosna de los

8 Cybele Vidal Neto Fernandes (2012). “A decoração do século XIX no Rio de Janeiro. Propondo questões”, Anais do XXXII Colóquio CBHA 2012: Direcões e sentidos da História da Arte. Brasilia: Universidade de Brasilia, p. 507. Esta historiadora del arte es la mejor conocedora del maestro Castro, que fue estudiante y miembro de la Academia Imperial de Belas Artes de Río de Janeiro. Entre su producción científica destaca A talha religiosa da segunda metade do século XIX no Rio de Janeiro através de seu artista maior Antônio de Pádua e Castro. Rio de Janeiro: EBA/UFRJ. Tesis de maestría, 1991. Con relación específica a las obras citadas en este artículo, véase "Entre a Academia e as Ordens Terceiras. Antônio de Pádua e Castro e o gosto na corte de d. Pedro II", Arthur Valle e Camila Dazzi (2008), Oitocentos. Arte brasileira do Império à República, t. I. Rio de Janeiro: EBA/UFRJ, pp. 331-339. 
feligreses han los suplicantes iniciado las obras que se hallan muy atrasadas por falta de rendimentos para ella". Como fecha de conclusión, o al menos de que el edificio se hallase en un estado avanzado de construcción y, posiblemente, de decoración, apuntamos al 18 de junio de 1844. En ese momento se inicia un pleito entre la parroquia de Santa Ana y la Hermandad del Santísimo Sacramento, en el que media la Câmara Municipal de Río, donde la primera solicita al emperador que resuelva no conceder la petición de la Hermandad de "plantar un recinto de un atrio [se refiere a un cementerio] que fuera cerrado para ese fin en el edificio que por Vuestra Majestad Imperial les fue concedido para la nueva matriz de Santa Ana (...)"10. Lo que no indica el documento es que la apertura de cementerios fuera de los templos, como medidas sanitarias implantadas bajo el reinado de D. Pedro II, era la pauta cuando los edificios estaban concluidos. Esto indica que por entonces se estaría trabajando en el ornamento en madera y estucos que envuelve todo el edificio.

Elegimos este templo culminado a mediados del Ochocientos como pervivencia del modelo barroco en el interior del templo, en el que destaca la gran bóveda de la nave mayor cubierta por madera, las capillas laterales coronadas por tribunas y un fastuoso tabernáculo clasicista de cúpula oval en la capilla mayor. En todo el conjunto predomina la abundancia de las rocallas, hojarascas, guirnaldas y todo tipo de repertorios ornamentales que sobresale en las tribunas abiertas sobre las naves laterales y los púlpitos. Por ello, no es descabellado pensar que la decoración barroca en yeso y madera fuese dirigida por Antônio de Pádua e Castro o alguno de sus ayudantes, al coincidir en el tiempo con las obras en los hermanos terceros carmelitas. En la fachada se dotó al proyecto de dos monumentales torres y un frontón con cierta afectación clasicista a la manera vignolesca. Esta convivencia sin complejos de los estilos clásico y barroco (considerando la raíz clásica del propio barroco), en pleno siglo XIX, es lo que nos gusta denominar como "estilo carioca", donde sobresale sin complejos la talla expresamente ornamentada con retablos encimados por tarjas con rocallas, el juego de líneas curvas, cornisas sinuosas y, en fin, todo un repertorio barroco, repentinamente mezclada con recursos clasicistas, de referencias vitruvianas. Por ello, apuntamos hacia un sentido estético definido por el ya citado entallador Antônio Pádua e Castro, que personifica para la historiografía del arte ese modelo y que podemos rastrear en las publicaciones de Benjamin Carvalho (1966: 106-111), donde apunta hacia su autoría como la mente creativa de este estilo tan propio del siglo XIX.

Otro caso singular es la decoración del interior del templo de la Orden Tercera de los hermanos mínimos de San Francisco de Paula, en el centro de la ciudad. La capilla, creada en 1759, sufrió un largo proceso de obras que concluyeron en los primeros años del siglo XX, incorporando elementos del lenguaje arquitectónico clasicista, pero la decoración en madera y yeso del interior fue ejecutada por Antônio de Pádua e Castro desde 1854, siguiendo los diseños en los que participó el pintor milanés Mario Bragaldi (Leite, 1988: 84). En este caso, el exceso del ornato, la hojarasca que desciende por la capilla mayor y sus tribunas, las bóvedas, paredes de la nave, arcos, que también invade el púlpito y, en general, todas las superficies del templo, pone de manifiesto que cualquier forma clasicista solo era concebida a mediados del siglo XIX en la arquitectura y el diseño de fachadas, con una tímida presencia de detalles en los interiores. La exteriorización del poder divino presente en el interior del templo, como trasunto a su vez de la autoestima de las élites dominantes, encontró en la ornamentación barroca su forma más legítima de expresión. Podría decirse, finalmente, que el barroco no es tanto una cuestión de gusto artístico sino la evidencia de un ideal social en una cultura alejada de los debates intelectuales que, de forma eficaz, se exteriorizaba e imponía sobre las academias creadas bajo el gusto clasicista, entidades que solo eran consultivas y no obligatoriamente definidoras de un nuevo patrón estético.

En el lado opuesto, como excepción, se halla la fastuosa construcción de la iglesia de Nossa Senhora da Candelária, concebida como un templo de dimensiones verdaderamente faraónicas para los primeros años del siglo XIX y que no se vio modificada por ornatos

9 Biblioteca Nacional do Rio de Janeiro, Divisão de Manuscritos, II-34, 29, 01, fol. 1r. Traducción de nuestra autoría.

10 Biblioteca Nacional do Rio de Janeiro, Divisão de Manuscritos, II, 24, 36, 013, fol. 1r. Traducción de nuestra autoría. 


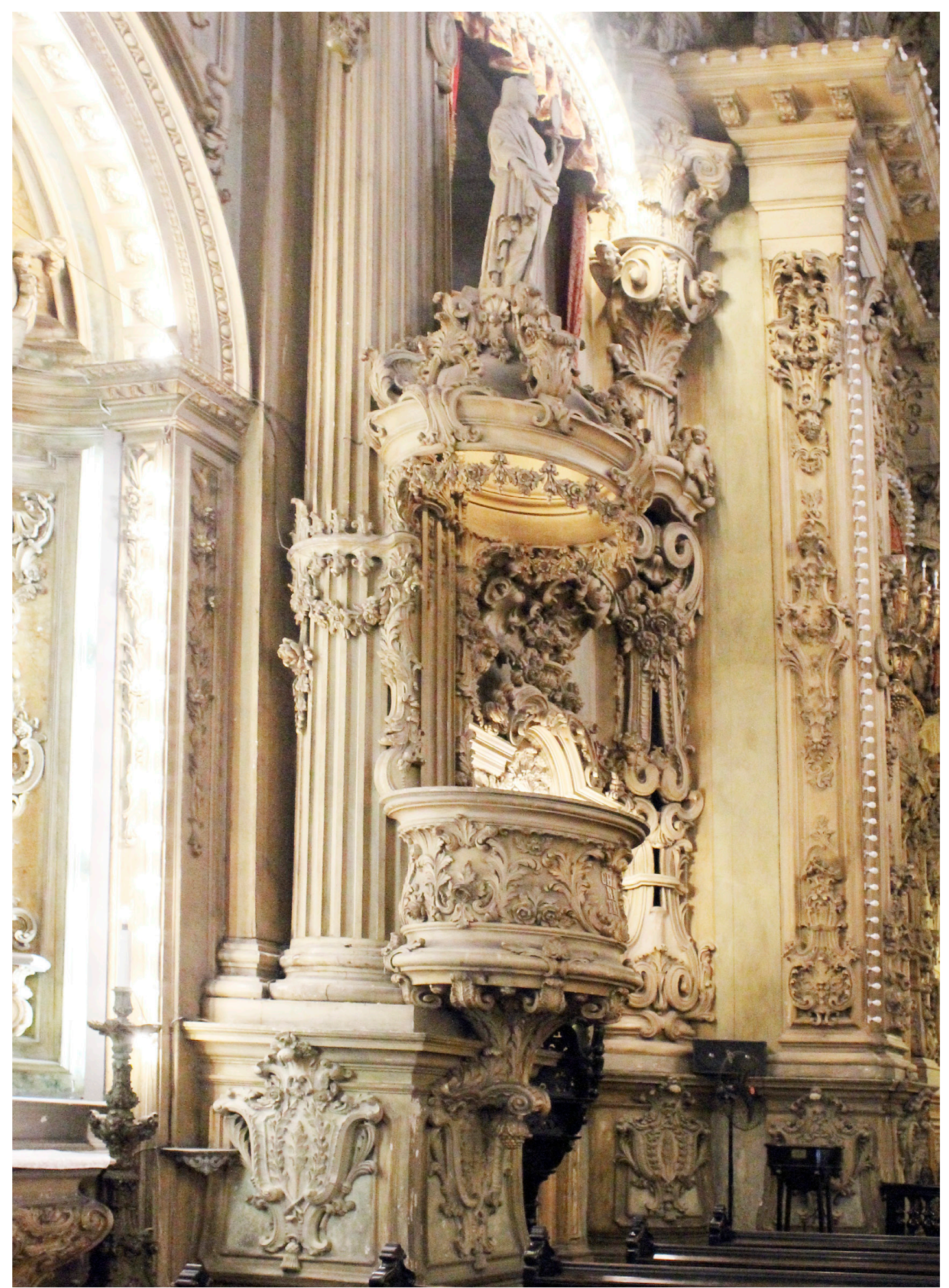

Figura 6. Decoración de la nave central y púlpito. Iglesia se São Francisco de Paula. Antônio de Pádua e Castro. C. 1854. Rio de Janeiro. Fotografía del autor

barrocos durante su construcción; de hecho posee pocos retablos, todos de filiación clasicista y en la decoración plástica, apenas destacan las pinturas de la bóveda, ejecutadas por el pintor Zeferino da Costa hacia 1898, retratando la historia del templo desde su fundación por canarios de la isla de La Palma (Castro, 2010: 73-94). Es uno de los pocos casos donde el gusto barroco no se manifestó en la ciudad de Río. O tal vez sí.

Este caso es verdaderamente singular porque transmite el combate entre clasicismo y barroco que se desata en el Río ochocentista. La Hermandad del Santísimo Sacramento de la feligresía de Nuestra Señora de la Candelaria decidió levantar un nuevo templo en 1775, y la documentación generada a partir de entonces es una de las mejores fuentes conservadas para 


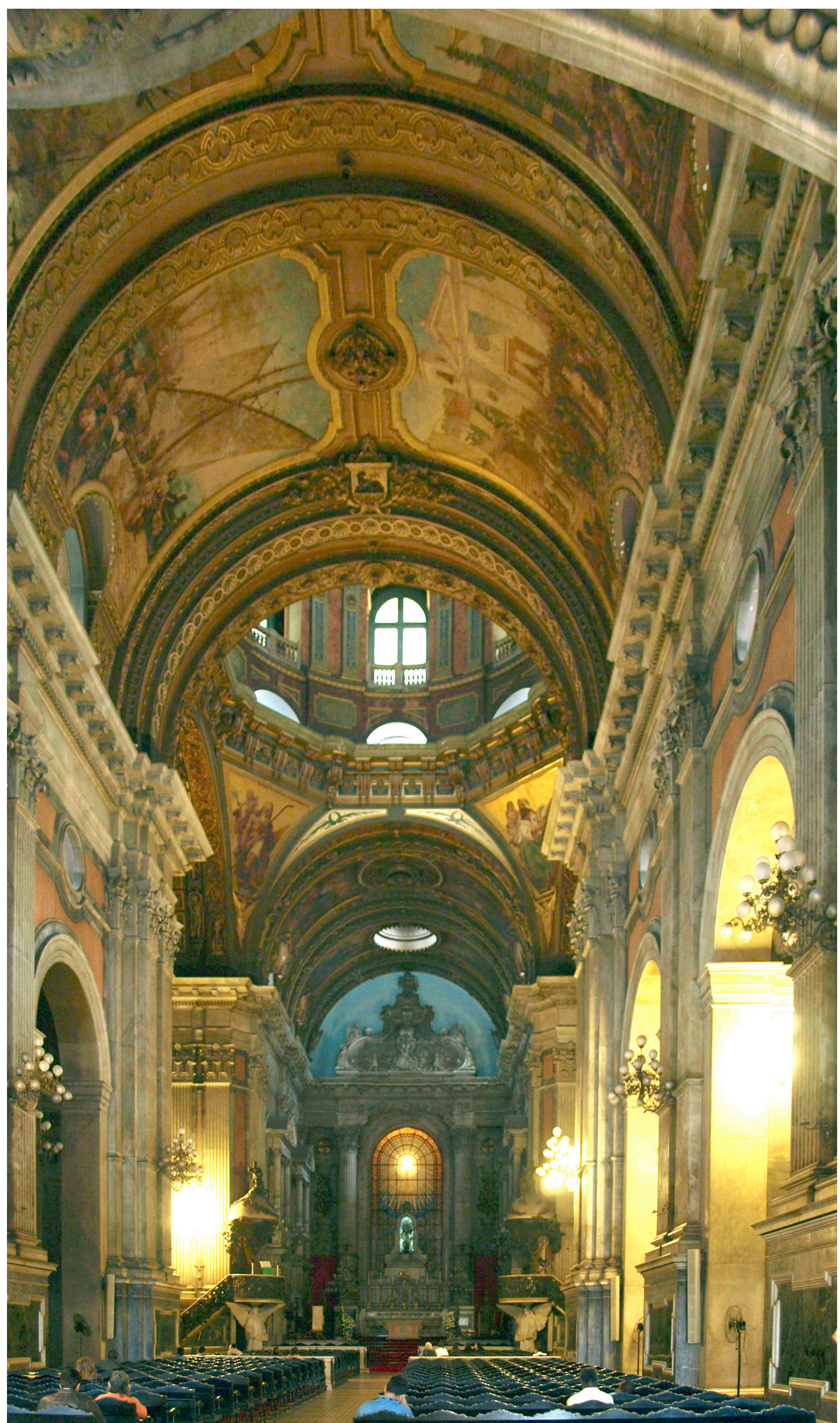

Figura 7. Interior de la Iglesia de Nossa Senhora da Candelária. 1812-1877. Río de Janeiro. Fotografía del autor 
la investigación sobre la historia del arte carioca y su evolución en el siglo XIX. Hemos podido consultar los fondos de la Hermandad, que hemos registrado en investigaciones anteriores, pero el trabajo de Marques Pinheiro de 1930 ofrece tanta y variada documentación (mucha desparecida con posterioridad a la publicación de su libro, por motivos diferentes) que su texto es en sí mismo una fuente para los estudios en arte. Según los documentos, hacia 1812 se hallaría realizada parte de la nave central y la fachada, para la que se había elegido un proyecto que podríamos clasificar como clasicismo barroco, firmado por el ingeniero Roscio; pero el verdadero debate se establece a la hora de edificar el cimborrio hacia finales de la década de 1860. Por entonces se presenta una idea firmada por el ingeniero Job Justino de Alcântara, según la cual estaría conformado de madera revestida de ornamentación (Pinheiro, 1930: 131). Sin embargo, en 1870 la Mesa de la Hermandad, o junta de gobierno, estima otra propuesta del ingeniero Daniel Ferro Cardoso, continuada por Evaristo Xavier da Veiga y concluida por Antônio de Paula Freitas, según la cual sería más adecuado realizarla en ladrillo y cantería el tambor, y piedra de lioz la cúpula, ajustándose a cánones renovados en los gustos arquitectónicos (Pinheiro, 1930: 140-183). La edificación se coronó en 1877. Este largo proceso, un verdadero combate bien documentado, no deja de representar las fricciones entre lo antiguo (barroco) representada por Alcântara, como fin de una era que fue rechazada, y lo nuevo (clasicismo) bajo el proyecto de Ferro Cardoso, como apertura grandilocuente de un tiempo futuro. Para completar la idea de "lo moderno", dicho cimborrio se vio coronado por ocho esculturas de mármol que representan a las virtudes y santos, que, en esencia, significan un cambio de patrón de gusto y modernidad.

José Victorino de Souza, cronista carioca de la época, acompañó la erección del templo y en 1889 publicó su historia, resumiendo todas las peripecias, incluido el intenso debate sobre el cimborrio. Sin embargo, nos llama la atención que reproduce la carta enviada por el escultor Angelo Sasella, profesor de arquitectura en Pisa y de la Academia de Bellas Artes de Carrara, en la que destaca su impresión de las obras de mármol que adornarán el templo: "Acertadamente aplicados son los órdenes, tanto de los principales como de las secundarios, de las tribunas, en las cuales transparece un vaguisimo coríntio, poética y bien ideada ornamentación que adorna los fustes, los capiteles, basas, arcadas y puertas, para las cuales todas las palabras son pocas..." (Souza, 1998: 69). Estas referencias, que descontextualizadas no parecen decir gran cosa, al ser subrayadas por Souza ganan un gran valor, pues admiran la conquista de lo clásico como base de la modernidad que debe presidir la cultura carioca. Pero no olvidemos que esta exaltación se refiere a acontecimientos de la década de 1870. Los auténticos avances de la teoría y praxis arquitectónica de la revolución industrial poco se destacan, más allá del uso secundario del hierro. Sin embargo, el cimborrio y todo el conjunto de la iglesia de la Candelaria, por mucha novedad que representase para Río, no deja de ser un eco lejano del lenguaje que nace del clasicismo barroco en Santa Inés en la Piazza Navona de Roma, proyectada por Giorolamo y Carlo Rainaldi en 1652, luego continuada por Francesco Borromini, que influye en San Carlos Borromeo de Viena por Fischer von Erlach iniciada en 1716, que influye en la planta de la basílica de Nossa Senhora da Estrela de Lisboa, por Mateus Vicente de Oliveira en 1779, continuada por Reinaldo Manuel dos Santos. Es cierto que entre esos templos hay tiempo y diferencias estructurales, pero el modelo arquitectónico heredado en la capital fluminense no deja de tener un trasfondo barroco que se remonta a la Roma de los Rainaldi, aunque la adopción de ese lenguaje para la iglesia de la Candelaria no deja de ser un símbolo creativo de una nueva era.

Ya hemos escrito sobre gusto, estética y evidencias artísticas y creativas, así como los artífices intelectuales de esta continuación en los patrones de gusto. La gran pregunta sigue siendo, ¿quién influye en los paradigmas estéticos y en el combate entre tradición y evolución de las artes en Río de Janeiro durante este siglo? ¿quién marca las "modas artísticas"?

Todo lo relatado parece alertarnos sobre una realidad: mientras la corte se esforzaba por introducir el gusto neoclásico llegado gracias a los franceses, evidente en sus proyectos plásticos y arquitectónicos, los patrocinadores y artistas de la excolonia, luego corte temporal y ahora cabeza del Imperio del Brasil, continuaban apegados a las formas ornamentales barrocas sin que ello supusiese una renuncia explícita al uso de elementos clasicistas; es decir, que la estética, como apreciación de la belleza, continuaba atávicamente unida al Barroco. Pero en estos templos, donde se junta la piedad de las clases acomodadas con las 
clases humildes, esclavos y libertos, la vivencia cultural del espíritu ilustrado, que resulta en el gusto neoclásico, está muy lejos del imaginario colectivo fluminense. En él continúan rigiendo los patrones sociales del Estado Moderno con relación al poder civil, el comercio sujeto a la prosperidad del estado imperial y la obediencia indiscutible de las clases humildes, por supuesto, asentado en el trabajo de los esclavos, quienes sustentarán la base de este régimen hasta la abolición en 1888. Es decir, que todos comparten espacios comunes, pero la separación social y racial es férrea, en las antípodas del pensamiento ilustrado.

De hecho, todos los viajeros que pasaron por Río de Janeiro durante el siglo XIX no se admiraban por la tímida modernización de la ciudad, tímida pero visible, sino por los arraigados trazos de la sociedad colonial, tan vivos como si nos hallásemos aún en la plenitud del Setecientos. Por esta razón, el artista que trabajaba para los entornos religiosos y sus patrocinadores, continuaba siendo anónimo o, como mucho, conocido por cartas de pagos u otras tipologías documentales que recogen datos económicos sin valorar la cualidad de la producción, a diferencia de los artistas del entorno cortesano o académico, protagonistas de los periódicos cariocas y beneficiados por bolsas de viaje para formarse en París o Roma. Sin embargo, para los artistas sobre los que pesa la tradición, las fuentes documentales del siglo XIX son a veces tan escasas en datos como en los siglos anteriores. Las mencionadas cartas de pago revelan que la mayoría de los artífices eran mulatos, es decir, antiguos escravos forros (libertos) ahora dedicados a la penosa profesión de artistas, y decimos esto porque en la sociedad esclavista decimonónica se despreciaba el esfuerzo creativo de los negros, aunque causasen orgullo los resultados artísticos obtenidos (Karasch, 2000: 307-313), y poca fortuna alcanzaban los artífices blancos que trabajaban para las hermandades, de ahí el silencio documental, sin contar con la desaparición de archivos por incendios, robos o, lo más triste y frecuente, la ignorancia que ha conducido a su destrucción, materia sobre la que poseemos abundante información oral de los herederos de ese patrimonio artístico, que se quejan de no poseer fuentes documentales por el último motivo aducido. Así pues, el reconocimiento solo se concedía a los artistas formados bajo la influencia de la Academia Imperial de Belas-Artes, es decir, para quienes construían o diseñaban "a la moda", sobre todo de París, para un cliente moderno, y sus proyectos sólo se harían realidad en una etapa tardía del siglo XIX y en un entorno reducido, el de la mencionada Academia y de sus admiradores.

\section{CONCLUSIONES.}

En 1878 el cronista y escritor carioca Joaquim Manoel de Macedo (1820-1882) publicó un libro titulado Um passeio pela cidade do Rio de Janeiro en el que entremezcla la descripción de la ciudad con pequeños relatos propios de ficción que se desenvuelven en barrios, plazas o calles, e incluye cartas o documentos de personajes célebres contemporáneos que aludían a aspectos concretos de la vida cotidiana en la capital brasileña. Uno de esos documentos es la reproducción de una carta del poeta, pintor y dramaturgo Manoel de Araújo Porto-Alegre (1806-1879), cuya formación transcurrió en Roma y, sobre todo, París y acabó siendo director de la Academia Imperial de Belas Artes. Dicha carta exaltaba la arquitectura de la iglesia de Santa Cruz dos Militares por incorporar un diseño clasicista, al que ya nos hemos referido en este artículo. Pero lo que nos ocupa ahora es leer un fragmento del texto en el que señala: "Si comparamos la fachada de la iglesia de la Cruz con las modernas de San José o del Sacramento, veremos un retroceso horroroso en los tiempos modernos y cuanto ha perdido la arquitectura en estos dos edificios que parecen salir de la misma forma bastarda e insignificante" (Macedo, 1991: 228) ${ }^{11}$. El lamento de este pintor evidencia que la decoración que en ocasiones adjetiva como "borrominesca", en claro tono despectivo, no era otra cosa que un lenguaje artístico vivo y vigente en la sociedad carioca de su tiempo, donde el clasicismo arquitectónico y el sentimiento romántico parisino aportado por los intelectuales aspiraba a un buscar reconocimiento, que frecuentemente se frustraba por la tozuda realidad que recordaba que el Brasil no estaba en Europa, sino en América del Sur.

Aseveramos, por tanto, que las formas y la estética barroca en Brasil, en general, y en Río, en particular, avanzan con toda naturalidad durante el siglo XIX. Es más, se trata de

11 Traducción de nuestra autoría. 


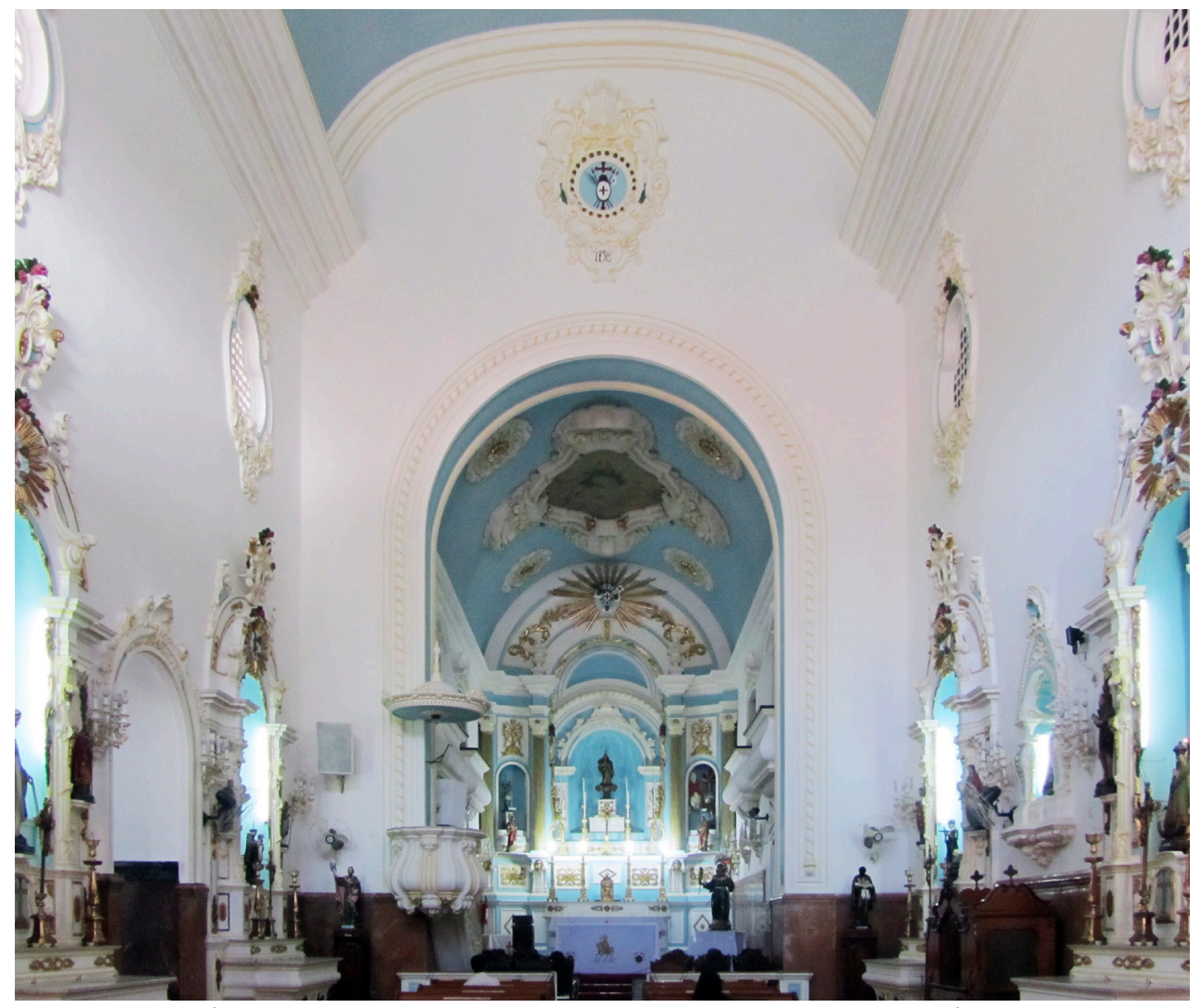

Figura 8. Decoración del interior de la Iglesia de São Jorge. Segunda mitad del siglo XIX. Río de Janeiro. Fotografía del autor

una constante de la brasilidad, porque emerge como dientes de sierra en los gustos sociales antes y después de la Léi Áurea de 1888, que abolió la esclavitud, conviviendo con momentos de preminencia clasicista en los encargos de Estado, preferentemente en obras públicas y laicas. Es decir, que la vivencia del barroco como forma de integración social, de convivencia, en torno a conceptos comunes, como la religiosidad o las ceremonias, ya sean católicas o sincréticas, ganará mucha fuerza a lo largo del siglo XIX difundiéndose la vida barroca como manera de ser social donde el negro gana una notoria expresión cultural gracias a la visibilidad de los rituales afrobrasileños en los espacios públicos, que toman para su expresión cultural la fiesta barroca. De hecho, a lo largo del siglo XX han sido muchos los intelectuales que han amado y odiado, a partes iguales, la identidad barroca como epidermis brasileña, unos por considerar el barroco como elemento identificador del tiempo colonial y otros por asumirlo como identificador del espíritu nacional (Cámara: 2013, 1-11). Efectivamente, la organización de los cultos de la religión de candomblé, de origen africano, está documentada ya hacia finales del siglo XVIII y en muchos aspectos toma costumbres o hábitos sociales vinculados a la liturgia católica (Dealtry, 2009: 19-44). Es el caso del templo de São Elesbão y Santa Efigênia de Río donde se cruzan rituales sincréticos entre los santos católicos y dignidades de esa religión, presente asimismo en la iglesia de São Gonçalo Garcia y São Jorge, de decoración barroca de la segunda mitad del siglo XIX que alberga el culto sincrético a São Jorge, patrono del Brasil y a la vez Ogum, orixá valiente que abre los caminos para los fieles de candomblé o umbanda. En pleno siglo XXI, el intenso aroma a cera de las velas, los estandartes y las colgaduras que tapan parcialmente la nave y altares de estos templos, adornados de molduras de estuco formando rocallas y guirnaldas, son visitadas por fieles, mayoritariamente negros, vestidos de blanco y mujeres cubiertas por turbantes y pano-da-cost $a^{12}$ para rendir culto a los

$\overline{12}$ Indumentos que en las religiones afrobrasileñas son fundamentales para entablar contacto espiritual con las entidades religiosas. 
santos (al mismo tiempo que orixás), mientras sujetan entre sus manos rosarios y cintas de colores que aluden al mismo tiempo a los santos/orixás protectores. La magia y el misterio de la atmósfera barroca aún respiran aquí con serena continuidad.

Por ello, las divisiones estilísticas y cronológicas, a nuestro juicio, se hacen añicos en Brasil. De hecho, sugerimos comprender el Ochocientos como un siglo parcialmente barroco, justamente apelando a este tipo de circunstancias, y rechazamos la aplicación de un método de investigación formalista de la historiografía europea para aproximarse al arte brasileño. Afirmamos que el siglo XIX es también un siglo del Barroco y no del Tardobarroco, puesto que este último concepto incluye modificaciones en el sentido ideológico y formal propias de las capitales cortesanas europeas, que no apreciamos en Río de Janeiro. De forma paralela, es obligatorio admitir que, en las mismas fechas, el sentido antibarroco que incluía numerosos elementos provenientes de la cultura clásica e ilustrada introducida por los extranjeros, mayoritariamente franceses, aunque también ingleses y alemanes, tanto en la arquitectura como en la decoración, fue una opción contemporánea fuertemente aceptada por la élite carioca "de Estado". A decir verdad, la influencia del Romanticismo, el género de la pintura de historia y los ecos de las primeras vanguardias en el entorno académico fluminense se limitó a quienes aspiraban a una mayor sofisticación parangonando a las cortes europeas, pero incluso el peso de esa élite no consiguió una fuerza suficiente para modificar el patrocinio local anclado en la tradición que promovía ese estilo barroco.

De aquí partimos hacia un segundo hecho. No podemos aceptar la frecuentísima costumbre de adjetivar una obra brasileña de los siglos XVIII y XIX como rococó. Realizamos esta afirmación porque en esa época no se conformaron élites al modo francés del Ancien Régime, que patrocinasen una estética tan laica como superficial, a la vez que lujosa en sus patrones de gusto. Es evidente y notorio el uso de formas decorativas rococó en retablos y otro mobiliario, pero ello no constituye una razón de peso para ser comparado el arte brasileño con la estética francesa, cortesana, burguesa y dieciochesca del tiempo de Luis XV o Luis XVI (Castro, 2004: 59-78). En este sentido, si rechazamos el empleo del concepto Ilustración y preferimos hablar de ilustrados en América, Brasil incluido, ¿por qué habríamos de hablar de Rococó en América, y no de elementos rococó, especialmente en Brasil? Podemos mencionar a personajes con hábitos importados del refinamiento de la Francia rococó, de elementos decorativos propios del mobiliario rococó, pero no de la estética plena del Rococó.

En este sentido, discordamos de una parte de historiografía del arte brasileña, que sostiene, siguiendo el formalismo, un periodo barroco hasta 1750 seguido de uno rococó en el que se encuadra la mayor y mejor parte del arte colonial -Aleijadinho, Ataíde y Mestre Valentim incluidos- y un periodo neoclásico abierto con la llegada de la Missão Artística de 1816. De hecho, esta visión eurocéntrica hoy resulta, además de extemporánea, confusa, ya que, al profundizar en la realidad artística brasileña, apreciamos una evolución dispar a la europea, y esta opinión está presente desde hace tiempo en muchos trabajos de investigación sobre el revisionismo que debe partir de una visión americana, e incluso sincrética (Shouse, 1998: 321-335).

Finalizamos señalando que nuestro juicio existe un periodo muy largo del Barroco, inaugurado en Río con las primeras manifestaciones culturales en el siglo XVII que atraviesa el espíritu creativo hasta la actualidad, pero que como estilo artístico nítidamente identificable pervive en las formas hasta, al menos, la proclamación de la República en 1889. Por supuesto, aceptamos que el Barroco decimonónico convive perfectamente con la llegada de las ideas ilustradas perceptibles en la organización social y cultural tras la instalación de la corte de d. João VI en 1808 y la progresiva arribada de extranjeros formados en el clasicismo y más tarde en el academicismo romántico. Pero nada resta al hecho de que Río es una ciudad nacida barroca que alcanzó su mayoría de edad siendo barroca y que aún hoy conserva trazos en la forma de vida, de relación social y costumbres de la población carioca. 


\section{BIBLIOGRAFÍA}

- Bazin, G. (1982). A arquitetura religiosa barroca no Brasil. Rio de Janeiro: Editora Record, vol. II.

- Belluzzo, A. M. (2000). O Brasil dos viajantes. São Paulo, Rio de Janeiro: Metalivros. Editorial Objetiva.

- Cámara, M. (2013). Atribuciones erróneas, lecturas anacrónicas: controversias barrocas en Brasil, Trazos neobarrocos en las poéticas latinoamericanas. Buenos Aires: Editorial Katatay, pp. 1-11.

- Carvalho, B. de A. (1966). Igrejas barrocas do Rio de Janeiro. Rio de Janeiro: Civilização Brasileira.

- Carvalho, M. P. De (2008). Uma idéia ilustrada de cidade: as transformações urbanas no Rio de Janeiro de D. João VI (1808-1821). Rio de Janeiro: Odisséia.

- Castro Brunetto, C. J. (2004). Crítica al uso del término rococó. El caso de Brasil, en C. J. Castro Brunetto (Ed.), Arte Barroco: una revisión desde la periferia (pp. 59-78). La Laguna: Fundación Cultural Mapfre-Guanarteme.

- Castro Brunetto, C. J. (2010). Los fundadores palmeros de la iglesia de la Candelaria de Río de Janeiro en el arte. Revista de Estudios Canarios, ( ${ }^{\circ}$ 54), pp. 73-94.

- Castro Brunetto, C. J. (2013). Arte popular y estética contemporánea en las escuelas de samba de Río de Janeiro, en P. Ordóñez Eslava y D. Martín López (Eds.), Between categories, beyond boundaires: arte, ciudad e identidad (pp. 112-130). Granada: Edición Librago.

- Cavalcanti, N. (2004). O Rio de Janeiro Setecentista. Rio de Janeiro: Jorge Zahar Ed.

- Chuva, Márcia (2003). Fundando a nação: a representação de um Brasil barroco, moderno e civilizado. TOPOI, $\mathrm{n}^{\circ}$ 4, pp. 313-333.

- Conduru, R. (2003). Grandjean de Montigny: um acadêmico na selva, em J. Bandeira, P. Martins Caldas Xexéo y R. (Eds.), A Missão Francesa (pp. 141-204). Rio de Janeiro: Editora Sextante Artes.

- Czajkowski, J. (Org.) (2000). Guia da arquitetura colonial, neoclássica e romântica no Rio de Janeiro. Rio de Janeiro: Casa da Palavra.

- Dealtry, G. F. (2009). No fio da navalha: malandragem na literatura e no samba. Rio de Janeiro: Casa da Palavra.

- Fernandes, C. V. N. (2012). A decoração do século XIX no Rio de Janeiro. Propondo questões. Anais do XXXII Colóquio CBHA 2012: Direções e sentidos da História da Arte. Brasilia: Universidade de Brasilia, pp. 497-508.

- Fernandes, C. V. N. (2008). Entre a Academia e as Ordens Terceiras. Antônio de Pádua e Castro e o gosto na corte de d. Pedro II, en A. Valle e C. (eds.), Oitocentos. Arte brasileira do Império à República, (t. I., pp. 331-339). Rio de Janeiro: EBA/UFRJ.

- França, J. M. C. (1999). Visões do Rio de Janeiro colonial: antologia de textos, 1531-1800. Rio de Janeiro: EdUERJ: José Olympio.

- Freyre, G. (1995). Casa-Grande \& Senzala. Rio de Janeiro: Editora Record.

- Gutiérrez, R. (1983). Arquitectura y urbanismo en Iberoamérica. Madrid: Manuales de Arte Cátedra.

- Gutiérrez, R. (1992). La transición del barroco al neoclasicismo en la cuenca del Plata. La obra de José Custódio de Sá e Faria. Boletín del Museo e Instituto 'Camón Aznar', n 48-49, pp. 151-152.

- Hoirisch, M, Salgado, M.S. y Ribeiro, R.T.M. (2009). Influência das Tecnologias Construtivas nas decisões de Projeto: uma análise da arquitetura neoclássica no Rio de Janeiro. Simpósio Brasileiro de Qualidade do Projeto no Ambiente Construído. São Paulo: Universidade de São Paulo, pp. 68-78. Disponible en: https://www.researchgate.net/profile/ Monica-Salgado-2/publication/269149207_Influencia_das_Tecnologias_Construtivas_ nas_decisoes_de_Projeto_uma_analise_da_arquitetura_neoclassica_no_Rio_de_Janeiro/ links/595d0aeb45851524687a567e/Influencia-das-Tecnologias-Construtivas-nas-decisoesde-Projeto-uma-analise-da-arquitetura-neoclassica-no-Rio-de-Janeiro.pdf [consultado el 10 de mayo de 2021]

- Homem, R. (2014). Arte y fe: sincretismo afrobrasileño”, Kaypunku: Revista de Estudios Interdisciplinarios de Arte y Cultura, $\mathrm{n}^{\circ} 1$, pp. pp. 25-39.

- Karasch, M. C. (2000). A vida dos escravos no Rio de Janeiro: 1808-1850. São Paulo: 
Companhia das Letras.

- Leite, J. R, T. (1988). Dicionário Crítico da pintura no Brasil. Rio de Janeiro: Artlivre.

- Lustosa, I. (2008). A igreja do Carmo na história do Rio de Janeiro, en M. Castro (Ed.), Igreja de Nossa Senhora do Carmo da Antiga Sé: história e restauração, (pp. 39-61). São Paulo: Companhia Editora Nacional.

- Macedo, J.M. de (1991). Um passeio pela cidade do Rio de Janeiro. Rio de Janeiro: Livraria Garnier.

- Martins, M. de S. N. (2012). A arte das corporações de ofícios: as irmandades e os trabalhos no Rio de Janeiro colonial, Clío: Revista de Pesquisa Histórica, no 30), pp.8-9.

- Oliveira, M.A. R. de (2003). O Rococó religioso no Brasil. São Paulo: Cosac \& Naif.

- Oliveira, M. A. R. de (2008). O rococó na Igreja do Carmo da Antiga Sé, en M. Castro (Ed.), Igreja do Carmo da Antiga Sé: História e Restauração, (pp. 107-118). São Paulo: Companhia Editora Nacional.

- Pereira, M. da S. (2000). Corpos escritos: variações do ser carioca e a tentação do monumental. Entre Europa e África: a invenção do carioca, (pp. 99-113). Rio de Janeiro: Topbooks.

- Pinheiro, F.B. M. (1930). Irmandade do Santíssimo Sacramento da Freguezia de Nossa Senhora da Candelária, (vol. I). Rio de Janeiro: Typografia do Jornal do Comércio.

- Priore, M. del y Venâncio, R. P. (2001). O Livro do Ouro da História do Brasil. Rio de Janeiro: Edidouro.

- Santos, A. M. P. dos, Santos, A. L. V. dos, Pereira, M. da S. P. y Peixoto, P. (2016). Gosto neoclássico: Grandjean de Montigny e a arquitetura no Brasil (1816-1850). Inventário e questões de método, en A. Cavalcanti, M. Malta. y S. G. Pereira (eds.) História da Escola de Belas Artes. Revisão crítica da sua trajetória, (pp. 68-87). Rio de Janeiro: EBA/UFRJ.

- Schultz, K. (2008). Versalhes Tropical: império, monarquia e a corte real portuguesa no Rio de Janeiro, 1808-1821. Rio de Janeiro: Civilização Brasileira.

- Seoane, J. (2000). La política moral del Rococó. Arte y cultura en los Orígenes del mundo moderno. Madrid: La Balsa de la Medusa.

- Shouse, C. (1998). Barroco, neobarroco y transculturación, en P. Schumm (Ed.), Barrocos y modernos. Nuevos caminos en la investigación del Barroco iberoamericano, (pp. 321-335). Madrid: Iberoamericana.

- Souza, J. V. de (1998). A igreja da Candelária desde a sua fundação. Rio de Janeiro: DebreT.

- Vera Lúcia Bottrel Tostes, V. L. B. (2008). O Rio de Janeiro no tempo de d. João VI, en V. L. B. Tostes (Ed.), Um novo mundo, um novo império: a corte portuguesa no Brasil, 1808-1822, (pp. 41-47). Rio de Janeiro: Museu Histórico Nacional.

- Wehling, A. y Wehling M. J. (1999). Formação do Brasil Colonial. Rio de Janeiro: Nova Fronteira.

- Xexéo, P. M. C. (2003). As artes visuais e a Missão Francesa no Brasil do século XIX, en J. Bandeira, P. M. C. Xexéo y R. Conduru (Eds.), A Missão Francesa, (pp. 67-139). Rio de Janeiro: Editora Sextante Artes. 